\title{
Historien som betydningsfuld i udforskning af en nutidig sundhedsfaglige problemstilling
}

\author{
Lisbeth Aaskov Falch \\ Ph.d. MHH, lektor, sygeplejerske
}

\begin{abstract}
The purpose of this article is to illustrate how historical fieldwork can make a significant contribution to exploring a contemporary health professional issue.

The article is based on my Ph.D. thesis: It is not our patient - a cultural-theoretical and culturalhistorical analysis of the importance of the organization of the hospital system for the hospitalization of old medical patients using Holbæk Hospital as an example, which among other things includes historical fieldwork to explore the current health care professional challenge.

The article briefly presents the Ph.D. project's research question, theory, method and analysis, as a background for subsequently exploring how historical fieldwork has been tackled, as well as examples of how historical exploration has made a valuable and significant contribution. Finally, there is a summary of the key points of the article.
\end{abstract}

Keywords: fieldwork, genealogy, hospital system, old patients, state- and Life-mode Theory, Foucault.

\section{Sammendrag}

Denne artikels formål er at udfolde, hvordan historisk feltarbejde kan bidrage betydningsfuldt til udforskning af en nutidig sundhedsfaglig problemstilling.

Artiklen tager afsæt i min ph.d.-afhandling: Det er ikke vores patient - en kulturteoretisk og kulturhistorisk analyse af betydningen af sygehusvæsenets indretning for gamle medicinske patienters indlæggelsesforløb med Holbæk Sygehus som eksempel, hvor der bl.a. indgår et historisk feltarbejde til at udforske den nutidige sundhedsfaglige problemstilling.

I artiklen præsenteres kort ph.d.-projektets forskningsspørgsmål, teori, metode og analyse, som baggrund for efterfølgende at udfolde hvordan det historiske feltarbejde blev grebet an, samt 
eksempler på hvordan den historiske udforskning har bidraget værdi- og betydningsfuldt. Afslutningsvis opsummeres artiklens centrale pointer.

Nøgleord: feltarbejde, genealogi, sygehusvæsen, gamle patienter, stats- og livsformsteorien, Foucault.

\section{Introduktion}

Hvordan kan gamle fotografier, avisscrapbøger, jubilæumsskrifter, sygehusinformationsblade og -telefonbøger samt en professors klageskrivelse fra 1800-tallet være med til at kaste lys over en aktuel sundhedsfaglig problemstilling? I denne artikel vil jeg, baseret på eksempler fra min ph.d.-afhandling (Falch, 2018), udfolde og argumentere for, hvordan historisk materiale kan bidrage analytisk til at afdække og udforske en problemstilling i sygehusregi i dag. Men også hvordan historisk feltarbejde kan gribes an metodisk, så det ikke bliver en vilkårlig empiriindsamling. Allerførst, vil jeg begynde med en kort præsentation af ph.d.-projektet.

\section{Baggrund}

I ph.d.-projektet har jeg udforsket forskningsspørgsmålet: "Hvordan får sygehusvæsenets indretning, baseret på specialisering og en særlig styringspraksis, betydning for gamle medicinske patienters indlæggelsesforl $\varnothing b$ ?" Fokuseringen på specialisering og særlig styringspraksis handler om, det var de træk af sygehusvæsenets indretning, der prægede organiseringen af de gamles forløb i mit gennemførte nutidige feltarbejde. Begrebet gamle er anvendt om patienterne, i stedet for ældre som er en relativ betegnelse. Dette for at afgrænse gruppen fra resten af befolkningen og for at præcisere, at gamle mennesker besidder særlige kendetegn og vilkår ved sygdom og indlæggelse (Schroll, 1983).

Baggrunden for forskningsspørgsmålets problemstilling stammer fra mine år som koordinerende sygeplejerske på en medicinsk afdeling. Her oplevede jeg, at de gamle ofte var uønskede på de medicinske specialafsnit, idet deres komplekse og rodede sygdomsbilleder med et væld af diagnoser betød, at de ikke passede ind i et specifikt speciale. Jeg blev ofte mødt med italesættelser som: "det er ikke vores patient!", når jeg ville flytte en af de gamle til et specialafsnit.

Formålet med ph.d.-projektet har været at frembringe ny viden om betydningen af sygehusvæsenets indretning for gamle medicinske patienters indlæggelsesforl $\emptyset \mathrm{b}$ set fra såvel statens, de sundhedsprofessionelles og de gamles perspektiv. Samt ny viden om hvordan det historisk er blevet til, at sygehusvæsenets "selvfølgelige" indretning i dag er en udfordring for gamles indlæggelsesforl $\varnothing \mathrm{b}$. Viden, der kan bidrage med perspektiver i praksisudviklingen af indretningen, så den i højere grad tilgodeser og understøtter gamle menneskers særlige vilkår, udfordringer og behov ved sygdom og indlæggelse.

For at afdække forskningsspørgsmålet har jeg arbejdet dialektisk med teori og empiri, der kontinuerligt har beriget, udfordret og udviklet hinanden gensidigt. Teorien har bestået af en 
sammentænkning af etnolog Thomas Højrups stats-og livsformsteori (Højrup, 2002) (Buus, 2001) og begreberne subjektivering, diskurs og styringsteknologi hentet hos filosoffen Michel Foucault (Foucault, 1988) (Foucault, 2000a) (Foucault, 2001).

Empirien udgøres af et historisk og et nutidigt feltarbejde på Holbæk Sygehus, der kan ses som eksemplarisk for sygehusudviklingen i Danmark og er stedet, hvor jeg blev ansat til at udforske problemstillingen. I det nutidige feltarbejde fulgte jeg 13 gamle medicinske patienters indlæggelsesforløb på Holbæk Sygehus og fors øgte at skabe og sammenholde empirien via feltobservationer, litteratur, dokumenter samt interview med 6 af de gamle og 20 sundhedsprofessionelle. Det historiske feltarbejde bestod af et forskningslitteraturstudium omhandlende den generelle historiske sygehusudvikling nationalt og internationalt. Samt af opslagsværker og alle former for overleveringer vedrørende Holbæk Sygehus.

På baggrund af en sammentænkning af teorien og forskningsspørgsmålets centrale begreber udviklede jeg en teoretisk begrebsstruktur, som har været styrende for skabelse af empirien og sidenhen analysen. Forskningsspørgsmålets to centrale begreber: "sygehusvæsenets indretning" og "gamle medicinske patienters indlæggelsesforløb" kan betragtes som praksisser i den danske stats indre indretning, der er blevet til, muliggjort og udviklet med det sigte kontinuerligt at matche sammenlignelige staters sygehusindretning og indlæggelsesforløb for gamle patienter. For den danske stat har det handlet om at forblive en anerkendt og suveræn stat i det internationale statssystem. Til brug i realisering af indretning og praksisser er sundhedsprofessionelle interpelleret, som har kunnet aktivere statens strategier, og som samtidig har interpelleret de gamle patienter, så de har opfattet praksisserne som selvfølgelige. Interpellation refererer til den proces, hvormed staten påkalder og danner sundhedsprofessionelle til at aktivere midlerne til opfyldelse af de politiske strategier (Buus, 2001, s. 105-106). De skiftende udefrakommende udfordringer stiller kontinuerligt nye krav til statens suverænitetsarbejde og indre organisering, hvorfor det vil være forskellige sundhedsprofessionelle, staten interpellerer på et givent historisk tidspunkt (Højrup, 2003, s. 34) og som derigennem udstyres med særlige kvalifikationer (Buus, 2001, s. 108). Interpellationen kan ses som en subjektivering jf. Foucault, hvor de sundhedsprofessionelle og de gamle gennem diskurser og styringsteknologier dannes på en måde, som er i overensstemmelse med statens strategi. Subjektivering referer til, hvordan mennesker kontinuerligt formes og dannes som subjekter i hverdagens sociale magtrelationer, hvorigennem de konstitueres og kategoriseres på bestemte måder. Subjektiveringen er udtryk for både en underkastelse og en selvdannelse, hvor mennesker underkastes bestemte sandheder, som de påtager sig og gør til deres egne (Foucault, 2000a, s. 331).

Som mit nutidige feltarbejde tydeliggjorde, så kommer sygehusvæsenets indretning i de gamles indlæggelsesforløb særligt til udtryk som tre praksisser; en særlig praksis for specialisering, styring og gamle medicinske patienters indlæggelsesforløb. Sygehusvæsenets specialiseringspraksis ses som afdelinger, afsnit og sundhedsprofessionelle, som har dygtiggjort sig inden for bestemte lægefaglige specialer, og dermed besidder specialistevner 
og -viden. Sygehusvæsenets styringspraksis forstås som den interpellation/subjektivering af borgere, der via strategier, diskurser og styringsværktøjer gøres til sundhedsprofessionelle, som realiserer og aktiverer de statslige sundhedspolitiske strategier. Praksis for gamle medicinske patienter ses som sygehusvæsenets professionelle praksis for gruppen af gamle i overensstemmelse med den til enhver tid gældende ældre- og sundhedspolitik. I spændingsfeltet mellem de tre praksisser, antog jeg, at betydningen af indretningen for gamles indlæggelsesforløb kunne indfanges.

Efterfø|gende gennemførte jeg en 4-dimensionel analyse både historisk og nutidigt af praksissernes realisering og udfoldelse, samt set fra henholdsvis statens, de sundhedsprofessionelles og de gamles perspektiv.

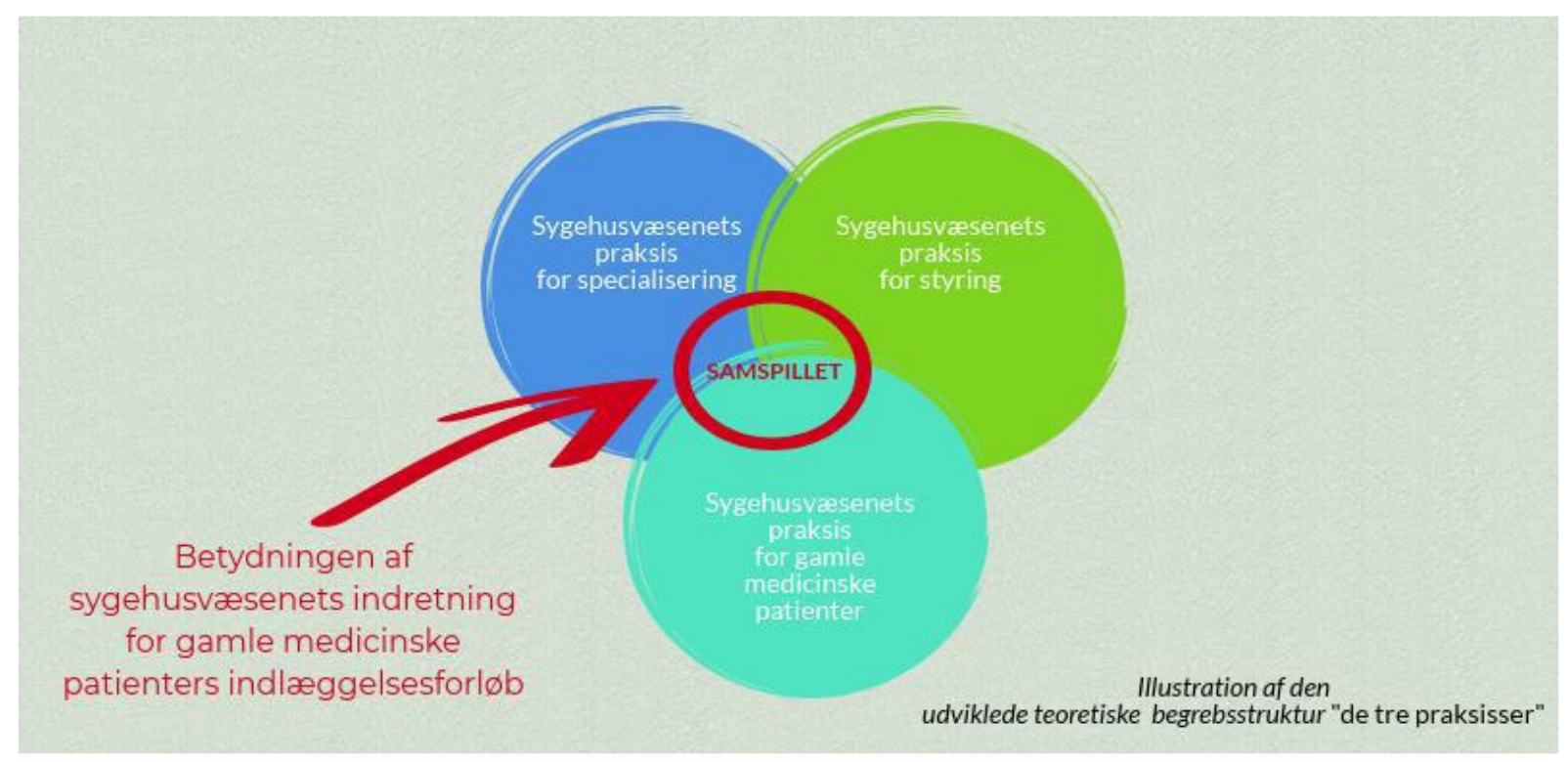

\section{Det historiske feltarbejde}

Som sagt, har det historiske feltarbejde været et af de metodiske værktøjer, jeg har anvendt i skabelse af empirien. I det følgende vil jeg udfolde, hvordan jeg greb det an.

\section{Sammentænkning af feltarbejde og genealogi}

Højrups stats- og livsformsteori og metode, samt Foucaults begreber og greb har udgjort en slags "rød tråd" gennem ph.d.-afhandlingen. Det vil sige, at ligesom jeg teoretisk har anvendt en sammentænkning af stats-og livsformsteorien og Foucaults begreber, har jeg tilsvarende metodisk i skabelsen af empirien sammentænkt feltarbejde og den genealogiske tilgang i vekselvirkning med den udviklede teoretiske begrebsstruktur. Stats-og livsformsteorien er udviklet inden for det etnologiske forskningsmiljø, som metodisk blandt andre gør brug af feltarbejde (Jespersen, Melchior \& Sandberg, 2006), mens Foucault arbejder med et historisk greb, som han bl.a. betegner genealogi (Foucault, 1977).

Feltarbejde dækker over en vifte af metode af alt fra feltobservation til dokumentanalyse, der anvendes for at opnå viden om selvfølgeligheder i måder at tænke og handle på, som produceres i sociale fællesskaber (Hastrup, 2015, s. 55 - 58). I feltarbejdet indgår at have blik for topografien, forstået som materialitet, geografi og historie. Ifølge antropolog Kirsten Hastrup er der sket en forskningsmæssig erkendelse: "en topografisk vending" af, at det sociale og det topografiske 
gensidigt konstituerer hinanden. Feltarbejdet tilbød et greb til at opnå viden om, hvordan praksisserne for specialisering, styring og gamle medicinske patienter udfoldes og materialiseres både nutidigt og historisk på Holbæk Sygehus. Sygehuset kan ses som udtryk for et socialt fællesskab, hvor der skabes selvfølgelige handlemåder i forhold til de tre praksisser, som kunne bringe mig nærmere, hvad den indretning har af betydning for gamles indlæggelsesforløb. Desuden muliggjorde feltarbejdet at opnå viden om, hvordan praksissernes udfoldelse ses ud fra henholdsvis statens, de sundhedsprofessionelles og de gamles perspektiv, samt de indbyrdes forhold, samspil og interpellationsprocesser.

Den genealogiske tilgang er en historisk fremgangs- og analysemåde, der søger at udfordre vores opfattelse af selvfølgelige institutioner og praksisser i dag. Det gør den ved at vise, at de har historiske rødder, som i rum og tid kan være langt fra det, som vi forbinder med dem, og at de indeholder problemstillinger, der stammer fra andre historiske og institutionelle sammenhænge, som gentages på nye måder. Med tilgangen udvælges bestemte nutidige fænomener eller diskurser, som følges tilbage i historien med henblik på at afdække deres historiske muligheds- og fremkomstbetingelser (Heede, 2007, kapitel 5). Foucault forklarer det selv i et interview: "I set out from a problem expressed in the terms current today and I try to work out its genealogy. Genealogy means that I begin my analysis from a question posed in the present" (Kritzman, 1988, s. 262). Genealogien er i tråd med Hastrups topografiske pointe om, at sociale fællesskaber med deres indlejrede selvfølgelige tænke- og handlemåder er konstitueret af historien. I genealogien ses tænkeog handlemåder som diskurser. Den genealogiske tilgang bistod med en måde at arbejde historisk, samt at problematisere de i dag selvfølgelige praksisser og diskurser inden for sygehusvæsenet.

Således, ved at sammentænke de to metoder, tilbød det etnologiske feltarbejde en metode til indsamling af både det nutidige og historiske materiale, mens den genealogiske tilgang bidrog med en fremgangsmåde at gå historisk til værks.

\section{At grave hvor man står...}

Feltarbejde fordrer en felt i form af et fysisk sted og rum, hvor menneskelige relationer og praksisser udfolder sig (Hastrup, 2015, s. 59), i det her tilfælde de tre praksissers udfoldelse. Oprindeligt, havde jeg planlagt at gennemføre den historiske udforskning på steder, som i historiske forskningsværker anses som værende eksemplariske for sygehusvæsenets- og dermed de tre praksissers udvikling. Samtidig, gennemførte jeg det nutidige feltarbejde på Holbæk Sygehus, som jeg ikke umiddelbart anså som værende historisk eksemplarisk eller rummende historisk materiale. I fors $\varnothing$ get på at være tro mod feltarbejdes metoden s $\varnothing$ gte jeg imidlertid lokalt på og omkring Holbæk Sygehus, og her afsløredes lag på lag af de tre praksissers lokale udfoldelse på en måde, som de historiske perioder har organiseret materialet. Det viste sig, at sygehuset har fulgt den strukturelle og generelle udvikling af provinssygehusene i Danmark og af praksisserne, og dermed kan anses som værende eksemplarisk. Den lokale historiske graven resulterede i fundet af et kælderarkiv på Holbæk Sygehus med metervis af materiale af alt fra avisscrapbøger til fotografier. Denne graven var i tråd med Foucaults egne genealogiske arbejder, som også tog afsæt lokalt med inddragelse af alt fra lægejournaler til avisreportager (Heede, 2007, s. 47). 


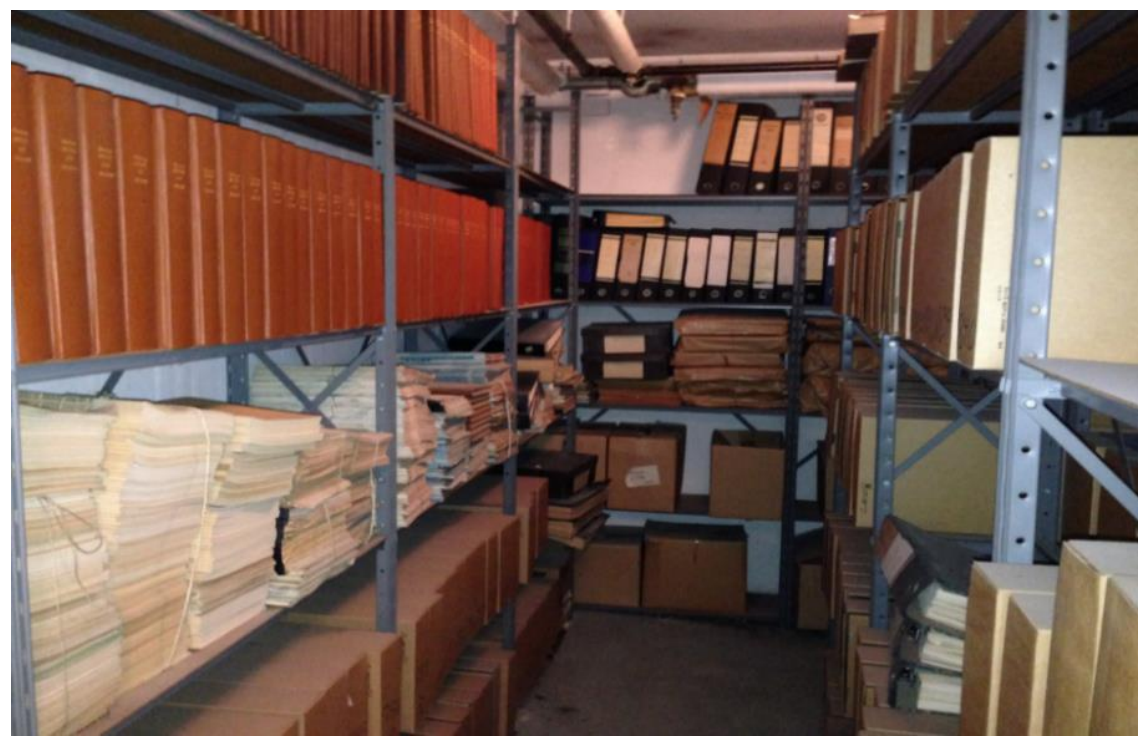

Kælderarkivet 2017

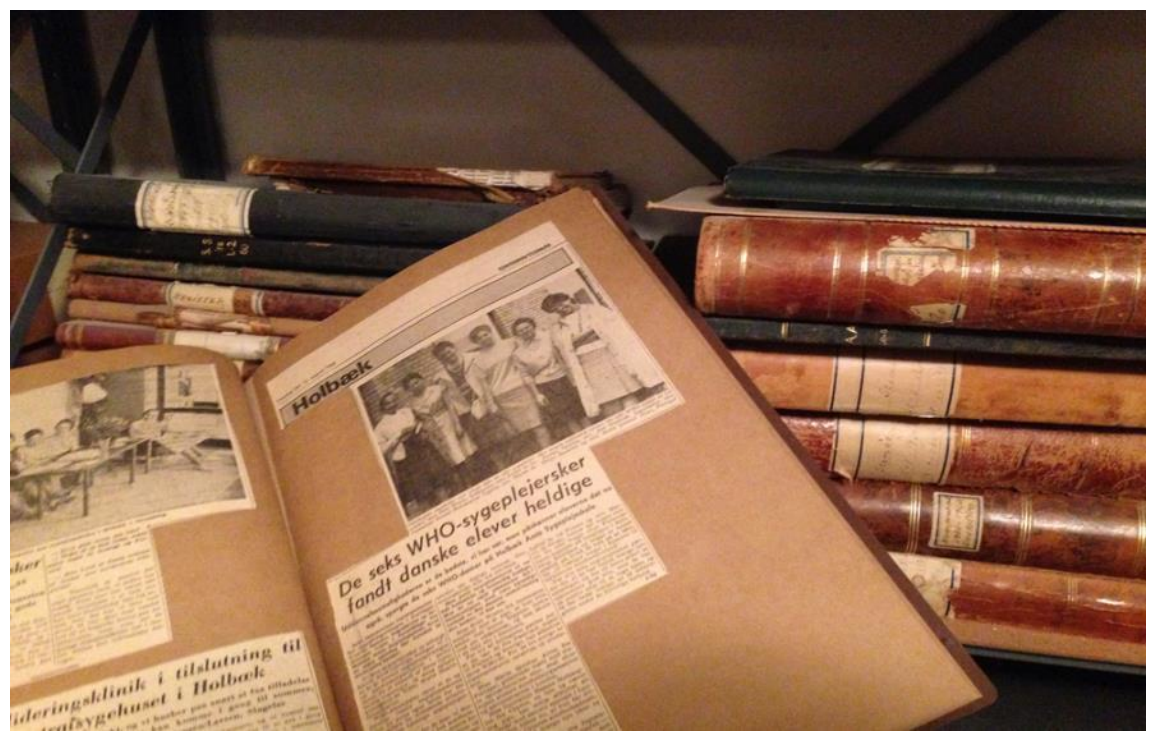

Scrapbøgerne fra kælderarkivet

\section{En disciplineret historisk opmærksomhed}

Udfordringen i historisk udforskning er, ifølge historikeren Knut Kjeldstadli, at det kan ende med "historie som rodekommode" (Kjeldstadli, 2001, s. 45), hvis man ikke præcis ved, hvad man forfølger i historien, mens Hastrup taler om, at feltarbejde fordrer "en disciplineret opmærksomhed" (Hastrup, 2015, s. 56). I forsøget på at tage højde for dette, har jeg anvendt, hvad jeg vil betegne som "en disciplineret historisk opmærksomhed", der har bestået af den udviklede teoretiske begrebsstruktur kombineret med den genealogiske tilgang og en periodisering.

Den teoretiske begrebsstruktur med de tre praksisser har været det perspektiv og det metodiske greb, der har afgrænset og hindret feltarbejdet $i$ at blive uoverskueligt og uhåndterbart. Med de tre praksisser som pejlemærke har jeg i tråd med den genealogiske tilgang gravet lag på lag historisk af deres udfoldelse tilbage til det tidspunkt, hvor de blev til i sygehusregi på Holbæk Sygehus. Endvidere har jeg periodiseret, forstået som at identificere perioder i historien, hvor der sker væsentlige og samtidige ændringer inden for det studerede (Kjeldstadli, 2001, s. 227-228), i mit tilfælde de tre praksisser og deres form i forhold til hinanden. Jeg har i bestemmelsen af de historiske perioder valgt, i overensstemmelse med ph.d.-afhandlingens teori, at gå med en kombination af Højrup og 
Foucault/Kuhn. Jeg har anvendt $\mathrm{H} \varnothing \mathrm{jrups}$ formbegreber til at finde frem til væsentlige og samtidige forandringer inden for praksisserne. De tre praksisser indgår i et dialektisk forhold, hvor de kontinuerligt former hinanden. Jeg har inddelt historien i perioder på baggrund af tidspunkter, hvor der sker forandringer i praksissernes indhold og samspil, der har forandret den form, som de indtager i forhold til hinanden. I bestemmelse af de historiske perioder har jeg på baggrund af praksissernes diskurser fors $\varnothing \mathrm{gt}$ at udlede det vidensparadigme, som gennemsyrer hver periodes verdensbillede. Inspireret af såvel Foucaults epistemebegreb (Heede, 2007) som Kuhns paradigmebegreb (Gustavsson 2001, s. 56). Hvor episteme basereres på mange former for viden, tager paradigme afsæt i den videnskabelige viden, mens begge begreber fors $\varnothing$ ger at indfange den herskende videnshorisont på et givent tidspunkt.

Periodiseringen førte til inddeling af Holbæk Sygehus' historie i tre perioder. Første historiske periode går fra 1800-tallet og frem til slutningen af 1920'erne, hvor den danske stats voksende interesse for borgernes ve og vel, i lighed med andre europæiske staters, udmøntede sig i opbygningen af et nationalt sygehusvæsen med blandt andet etablering af amtssygehuse i alle st $\varnothing$ rre købstæder. Det førte til oprettelsen af Holbæk Amtssygehus i 1844, hvormed der var skabt muligheds- og tilblivelsesbetingelserne i sygehusregi for praksisserne for specialisering, styring og gamle patienter i købstaden Holbæk. Den anden historiske periode går fra 1930'erne frem til slutningen af 1980'erne, hvor statens mål om sikring af borgernes velfærd førte til udbygning af det nationale sygehusvæsen, så det matchede andre europæiske staters. Det bet $\varnothing$ d, at mulighedsbetingelserne for de tre praksisser ændrede sig på Holbæk Amtssygehus, som blev til et centralsygehus. Den tredje og sidste historiske periode går fra 1990'erne frem til i dag. Den danske stats markedsgørelse af sygehusvæsenet med indførelse af New Public Management styringsværktøjer førte atter til ændrede mulighedsbetingelser for de tre praksisser på Holbæk Centralsygehus, som går fra at være et centralsygehus til et akutsygehus.

\section{Det historiske feltarbejdes bidrag}

Hvordan var det så at alt fra fotografier til avisscrapbøger kom til at bidrage betydningsfuldt til udforskningen af den nutidige sundhedsfaglige problemstilling? Det vil jeg udfolde i det følgende gennem fire eksempler. I eksemplerne er interviewpersoner fra det nutidige feltarbejde anonymiseret i overensstemmelse med god forskningsetik (Brinkmann, 2015), mens personer i det $\emptyset$ vrige tekst- og fotomateriale ikke er, idet materialet er frit tilgængeligt og hører under gældende lov om pligtaflevering, som led i bevaring af dansk kulturarv (Det Kongelige Bibliotek, 2020). Personerne i materialet betragtes ikke som enkeltpersoner, men som repræsentationer for positioner og praksisser.

\section{Historiske muligheds- og fremkomstbetingelser}

For det $f \varnothing r s t e$ har anvendelse af den genealogiske tilgang gjort det muligt at følge de tre praksisser tilbage i tiden for at kunne analysere og dermed afdække de historiske mulighedsog fremkomstbetingelser for problemstillingen. Det vil sige, hvornår og hvordan det blev til, at sygehusvæsenets selvfølgelige indretning i dag er en udfordring for gruppen af gamles indlæggelsesforløb.

Følger vi de tre praksisser tilbage, så blev der i den første historiske periode med oprettelse af Holbæk Amtssygehus i 1844 skabt muligheds- og tilblivelsesbetingelser i sygehusregi for praksisserne for specialisering, styring og gamle patienter.

Specialiseringspraksissen kom til udtryk i indretningen i form af opdeling og adskillelse af de 16 lemmer, 12 sindssyge og 12 somatisk syge (Birch-Jensen, 1944), som sygehuset havde plads til. 
Sygehuset bestod ved opførelsen af en T-formet bygning med en fløjtilbygning i hver ende af den vandrette bygning i T-et, som sammen med brandmure dannede to gårde. I den østlige gård var indgangsporten til sygehuset, mens den vestlige gård var opdelt i to mindre gårde til henholdsvis lemmer og sindssyge. De sindssyge og de somatisk syge havde til huse i den vandrette bygning, mens lemmerne var placeret i den lodrette midterfløj af T-et (Harpøth, 1944). Sygehusets behandlingspraksis var ikke specialiseret, idet sygehuset, i lighed med andre provinssygehuse i 1800 tallet, var indrettet som et såkaldt "blandet sygehus", hvor patienterne uanset sygdom, med undtagelse af de psykiske sygdomme, var placeret på samme sengestuer (Flindt, 1887a). Alle patienterne blev behandlet af samme læge, som tog sig af både de somatisk syge og de sindssyge (Birch-Jensen, 1944). Sidenhen kom specialiseringspraksissen til udtryk i udflytningen omkring 1890 af de psykisk syge og lemmerne til en ny-opført arbejds- og sindssygeanstalt, samt udflytningen i 1909 og 1910 af de epidemisk syge til henholdsvis et nybygget epidemisygehus og et tuberkulosehospital (Birch-Jensen, 1944).

Oprettelsen af amtssygehuset skabte behov for en styringspraksis, forstået som en interpellation af udvalgte borgere, der bidrog til realisering og aktivering af sygehusets praksis. Der var tale om professionalisering snarere end den specialisering, som på samme tidspunkt fandt sted i de store byer af lægerne. Specialiseringen af lægerne på amtssygehuset vandt først fodfæste i den næste historiske periode. Professionalisering kan ses som uddannelse og oplæring af borgere til at varetage bestemte opgaver (Højrup, 2002, s. 319). På sygehuset bestod professionaliseringen i ansættelse af en uddannet læge, en inspektør, en sygevogterske og tre piger (Birch-Jensen, 1944). De tre sidstnævnte grupper havde ikke en egentlig uddannelse. For inspektørerne havde de erfaring med virksomhedsdrift, mens sygevogtersken og pigerne blev oplært gennem arbejdet. I løbet af perioden kom uddannede sygeplejersker til (Flindt, 1887b) samt, som det fremgår af fotografi af amtssygehusets stab fra 1920-21, reservelæger, portører, kontorpersonale og en økonoma.

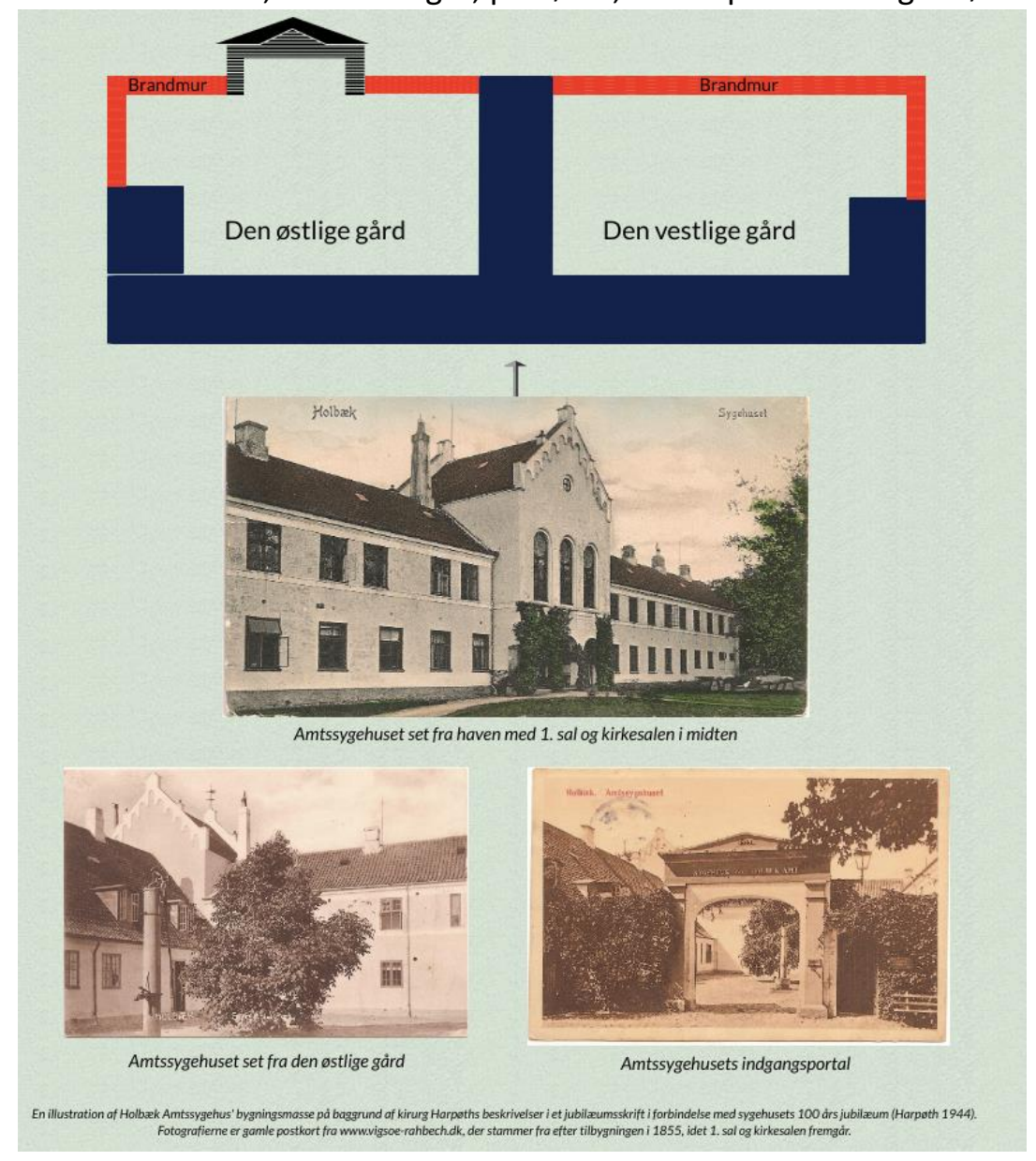




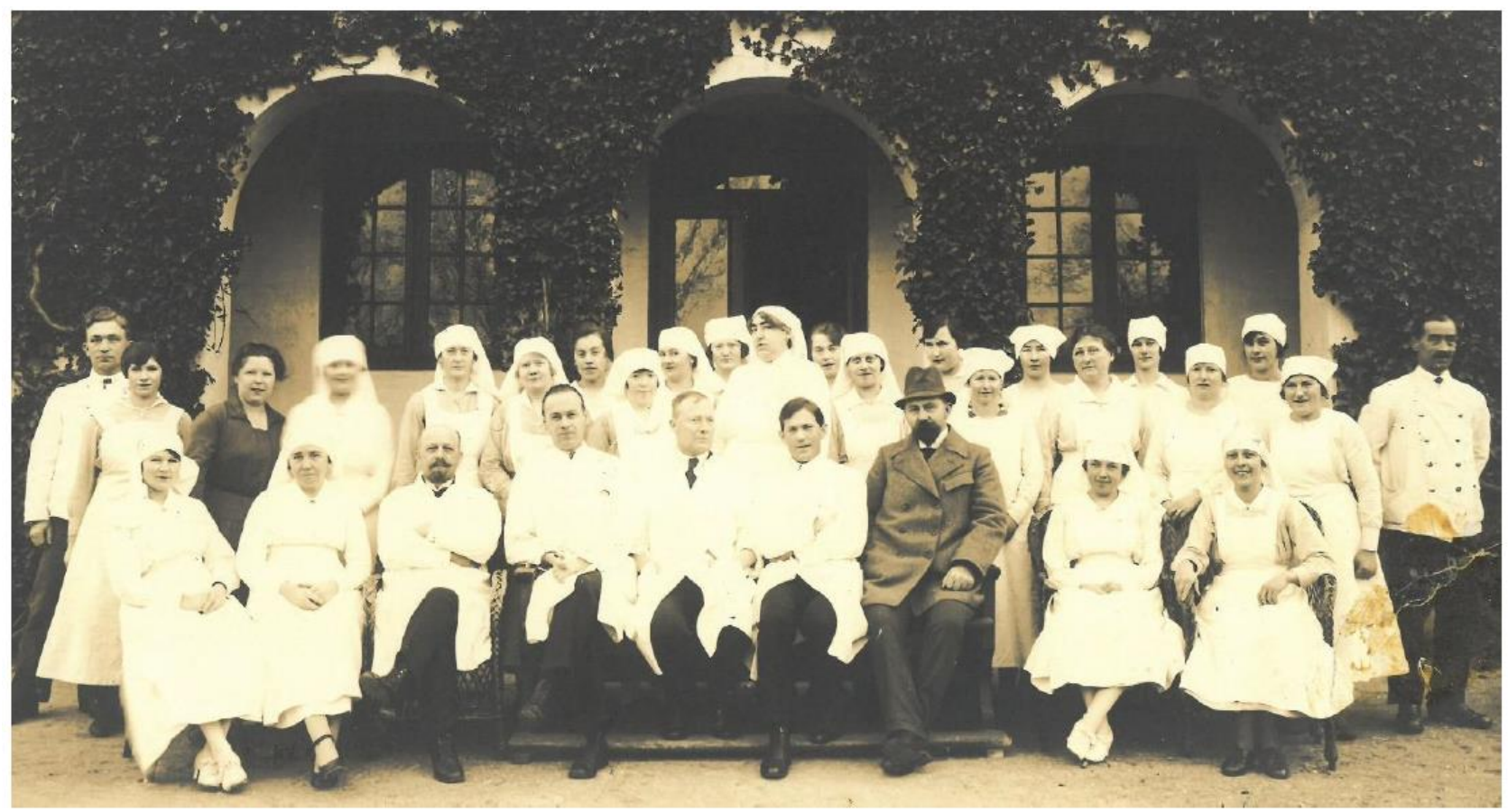

Holbæk Sygehus 1920-1921. (På forreste række fra venstre: to sygeplejersker med slør, herefter læge på Orø Rasmus Poulsen Rasmussen, reservelæge Møller Nielsen, kirurg Harpøth, reservelæge Iversen, inspektør Birch-Jensen, og igen to sygeplejersker med slør. På bagerste række fra venstre: en mandlig portør, en stuepige uden hovedbeklædning, mørkklædt kontordame frk. Ratche, tre sygeplejersker med slør, en stuepige uden hovedbeklædning, fire sygeplejersker med slør hvoraf den sidste er oversygeplejerske Mørch, en stuepige uden hovedbeklædning, fru Gerda Nielsen, to køkkenpiger med kappe, økonoma frk. Riber uden kappe, fire køkkenpiger med kappe og en mandlig portør). Kilde: Holbæk Museum

Der var med amtssygehuset skabt grundlag for en praksis for gamle mennesker i sygehusregi. Der var gamle blandt fattiglemmer og patienter, men der eksisterede ingen egentlig geriatrisk praksis. De første antydninger af en ændret praksis for gamle i købstaden Holbæk kom i 1908 med etableringen af alderdomshjemmet "De Gamles Hjem" (Kirkeskov \& Larsen, 1933, s. 95).

I den anden historiske periode blev mulighedsbetingelserne ændret inden for de tre praksisser på Holbæk Amtssygehus, som i 1937 overgik til et centralsygehus.

Specialiseringspraksissen på Holbæk Centralsygehus tog fart i både indretning og praksis. Det nyetablerede centralsygehus gik fra i 1937 at være indrettet med en medicinsk, en kirurgisk og en røntgenafdeling til i midten af 1970'erne at have, med få undtagelser, de typer af specialafdelinger, som også forefindes på sygehuset eller i regionen i dag. Centralsygehusets fire kirurgiske afdelinger var i 1970erne grenspecialiseret i parenkymkirurgi, ortopædkirurgi, gynækologi samt en operationsafdeling, mens det ikke var tilfældet for de fire medicinske afdelinger (Holbæk Centralsygehus, 1974b).

Centralsygehusets styringspraksis bestod, i lighed med den foregående periode, af interpellation af udvalgte borgere via professionalisering, samt i stigende grad specialisering. Ligesom andre styringsværktøjer også dukkede op. Den tiltagende specialisering skabte behov for speciallæger, som kontinuerligt kom til inden for de nyoprettede specialer. Hvor der med oprettelsen af centralsygehuset i 1937 var to specialoverlæger (Birch-Jensen, 1944), var det antal i 1969-70 steget til 23 specialoverlæger (Hertz, 1986, s. 302). Centralsygehusets udvikling skabte behov for flere sygeplejersker til at assistere lægerne, hvilket fra 1950'erne til 1970'erne resulterede i sygeplejerskemangel (Holbæk Amtstidende, 1950, 30. juni) (Holbæk Amts Venstreblad, 1953, 17. november) (Holbæk Amtstidende, 1962, 28. juni). I 1970'erne syntes sygeplejerskemanglen at klinge af (Sjællands Tidende, 1974, 19. december), hvilket kunne handle om, at sygehjælperne havde overtaget dele af sygeplejerskernes arbejdsopgaver. Ifølge mit feltarbejde, blev sygehjælperne til som en faggruppe på centralsygehuset i denne periode, men ikke grundet den daværende 
sygeplejerskemangel, som det er nærliggende at tænke i dag. Det handlede om, belært af 2 . verdenskrig og i lyset af den daværende kolde krig, at have et beredskab at kunne mobilisere ved fremtidige "krigs- og katastrofesituationer". Anvist af Sundhedsstyrelsen begyndte centralsygehuset i 1954 at uddanne "frivillige sygehjælpere", som blev hvervet i Holbækegnens husmoderforeninger og spejderkorps (Sjællands Posten, 1954, 17. februar). De frivillige sygehjælpere skulle være fyldt 20 år og "være af et godt helbred". De fik et kursus, der strakte sig over 17 aftener og omfattede spædbørnspleje, nødhjælp ved fødsel, medicingivning og hygiejne. Kurset blev efterfulgt af 20 timers $\varnothing$ velse på sygehuset og udstedelse af et uddannelsesbevis, hvorefter de kunne under sygehusets "travle perioder deltage i arbejdet" (Sjællands Posten, 1954, 9. marts). I 1960 overgik kurset til en formaliseret uddannelse rammesat af Sundhedsstyrelsen, og i 1962 berettede forstanderinde Hielm Schmidt, hvordan sygehjælperne gradvist var blevet en del af centralsygehusets plejepersonale (Holbæk Amts Venstreblad, 1962, 7. juli).

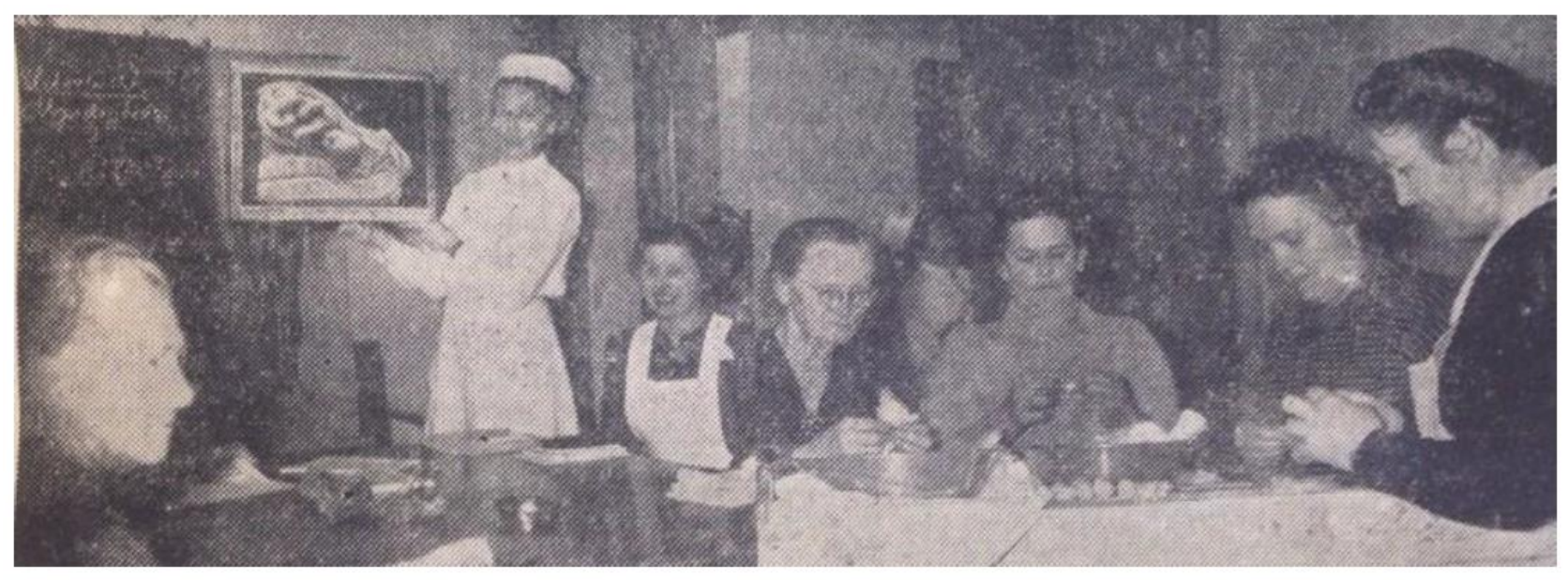

Fotografi fra uddannelsen af de frivillige sygehjæ/pere. Forstanderinde Hielm Schmidt fortæller om fostrets stilling, mens deltagerne fremstiller vattamponer. Kilde: Avisudklip fra scrapbøgerne fra Holbæk Amts Venstreblad 2. februar 1955.

Der blev, som led i professionaliseringen af centralsygehusets personale, satset på formaliseret uddannelse. Det handlede om uddannelse af sygeplejersker. I 1948 oprettede Holbæk Amt som det første amt i Danmark "en amtsforskole" for kommende sygeplejerskeelever på Holbæk Centralsygehus (Holbæk Amts Venstreblad, 1953, 17. november). Siden opførte Holbæk Amt i 1960 egen sygeplejeskole, der blev drevet af Holbæk Amt og Købstæderne Holbæk, Kalundborg og Nykøbing i fællesskab (Knudsen, Laulund, Andersen m.fl., 1962, s. 606-608). Det drejede sig også om sygehjælperne der, som beskrevet, i 1960 fik en formaliseret uddannelse.

Nye styringsværktøjer blev også introduceret. Det handlede om tværfaglige mødefora, der var nødvendiggjort af det $\varnothing$ gede behov for koordinering mellem de mange nye faggrupper. Som det fremgår af fotografi fra 1954, blev der afholdt fælleskonferencer for læger og afdelingssygeplejersker på ledende overkirurg Heibergs kontor. Det fremgår desuden af et forsidefotografi fra centralsygehusets daværende informationsblad med teksten: Morgenkonference på afdeling A4 (Holbæk Centralsygehus, 1974a), at der blev afholdt morgenkonferencer i 1974 på en af de kirurgiske afdelinger. 


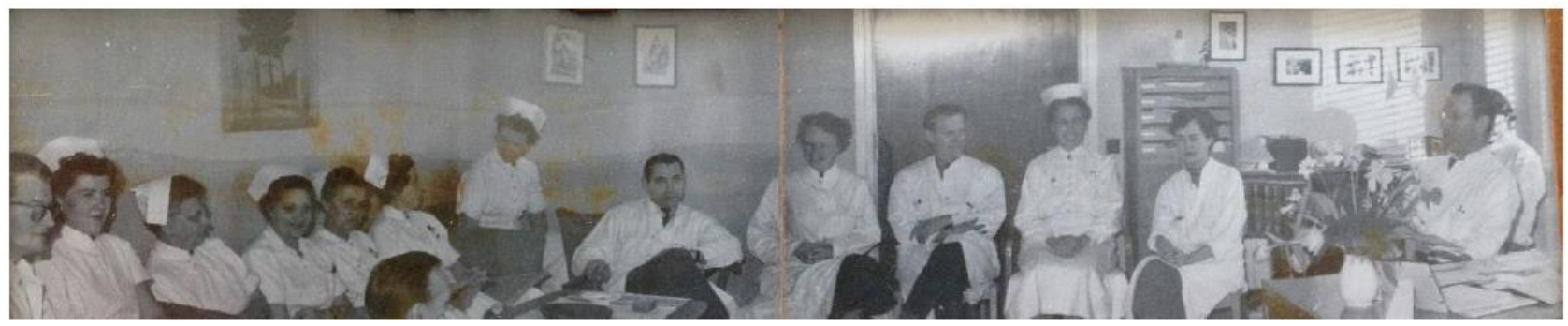

Fotografi af morgenkonference for overlæger, afdelingssygeplejersker og forstanderinde på overkirurg Heibergs kontor ca. 1954. Kilde: Holbæk Stadsarkiv.

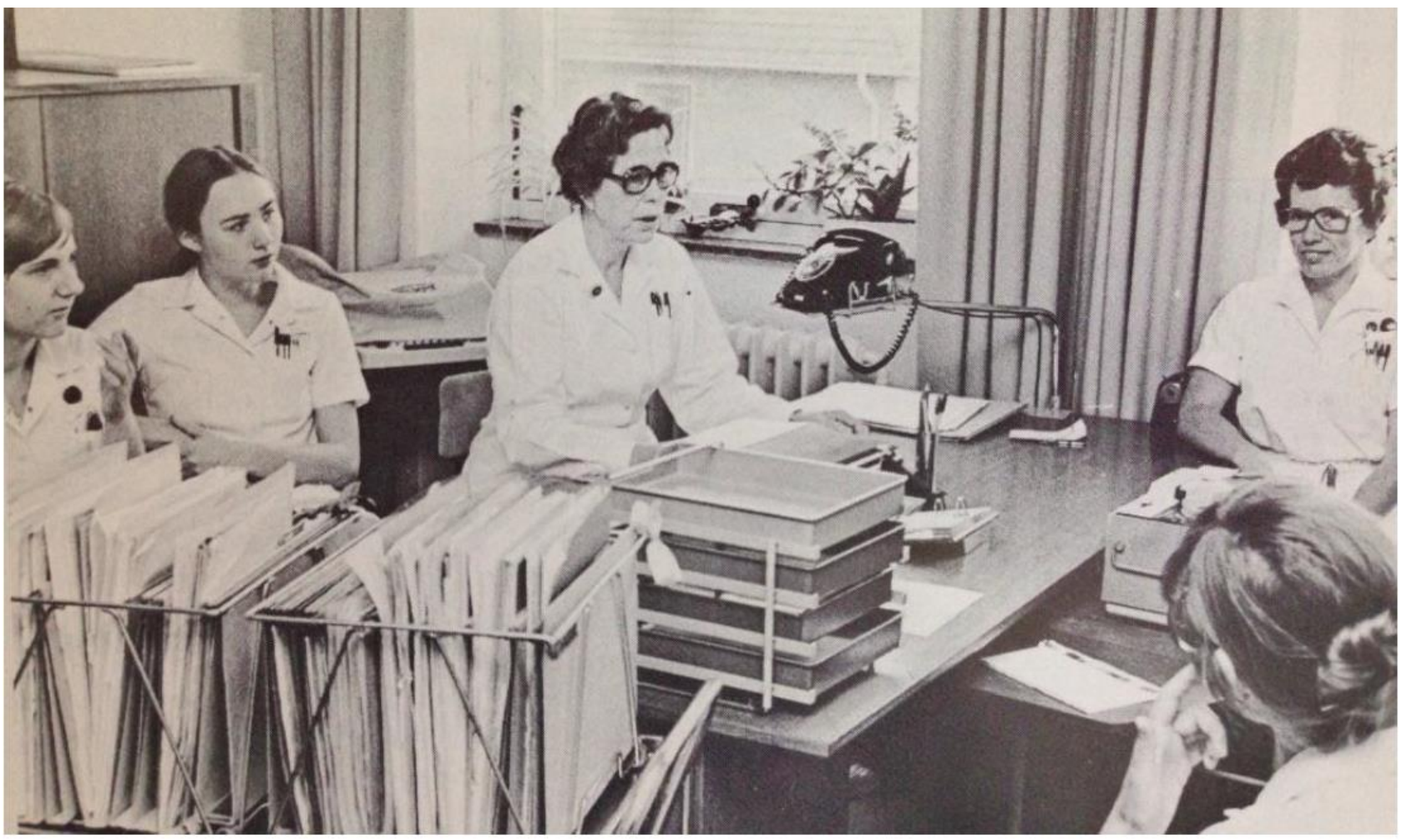

Forsidefotografi med teksten "Morgenkonference på afdeling A4" fra Sygehusbladet (Holbæk Centralsygehus 1974a)

Elektroniske styringsværktøjer blev tillige introduceret på centralsygehuset i 1970'erne og skabte mulighedsbetingelser for de styringsværktøjer, som kom til i den næste periode. I 1972 blev der indført EDB til indberetning af patient- og sygdomsregistreringer til Sundhedsstyrelsen.

Centralsygehusets daværende administrationschef Dissing Sørensen så potentiale i det nye styringsværktøj. Han udtalte eksempelvis: "med tiden følger sikkert flere udnyttelsesmuligheder for EDB-teknikken" (Sjællands Tidende, 1972, 7. april).

I denne periode blev udviklet en professionel praksis for gamle medicinske patienter. De gamle optog en stigende andel af de medicinske sengepladser, hvorfor der i 1960'erne blev oprettet et amtsplejehjem ved sygehusene i Holbæk Amt, der skulle tage sig af de mest plejekrævende og dermed aflaste de medicinske afdelinger (Holbæk Amts Venstreblad, 1964, 8. december) (Holbæk Amts Venstreblad, 1966, 26. marts). Blandt lægerne på centralsygehuset opstod en stigende interesse for sygdomme hos gamle mennesker. Overlæge Thomsen italesatte allerede i 1950'erne sygdomme hos gamle:

Det nye er de sygdomme, som hører alderdommen til og som ikke var saa udprægede før. Hvert alderstrin har sine sygdomme, og naar de yngre glider ud og folk $i$ det hele taget lever længere, bliver det andre sygdomme, der bliver væsentlige (...) Vort problem er at lære disse nye sygdomme at kende og bekæmpe dem (Holbæk Amtstidende, 1956, 18. august). 
Centralsygehusets stigende interesse for gamle førte til, at sygehusbestyrelsen i 1968 tog på bes $\varnothing \mathrm{g}$ på engelske, primært geriatriske, hospitaler for at indhente inspiration til håndteringen af den voksende gruppe af gamle patienter. Året efter etablerede sygehuset for syge gamle en langtidsmedicinsk afdeling, som siden blev til geriatrisk afdeling. Den langtidsmedicinske afdeling blev ledet af overlæge Hjermind, som allerede dengang berørte udfordringen med, at gamle mennesker kan komme i klemme i sygehusvæsenets specialiserede praksis, fordi som han udtrykte det: "Talrige ældre mennesker frembyder både medicinske, fysiurgisk - genoptræningsmæssige og social - geriatriske problemer". Han anså oprettelsen af de langtidsmedicinske afdelinger som en Iøsning af de gamles manglende indpasning i sygehusvæsenet og advokererede for et styrket samarbejde med primær sektor (Holbæk Amts Venstreblad, 1974, 5. januar).

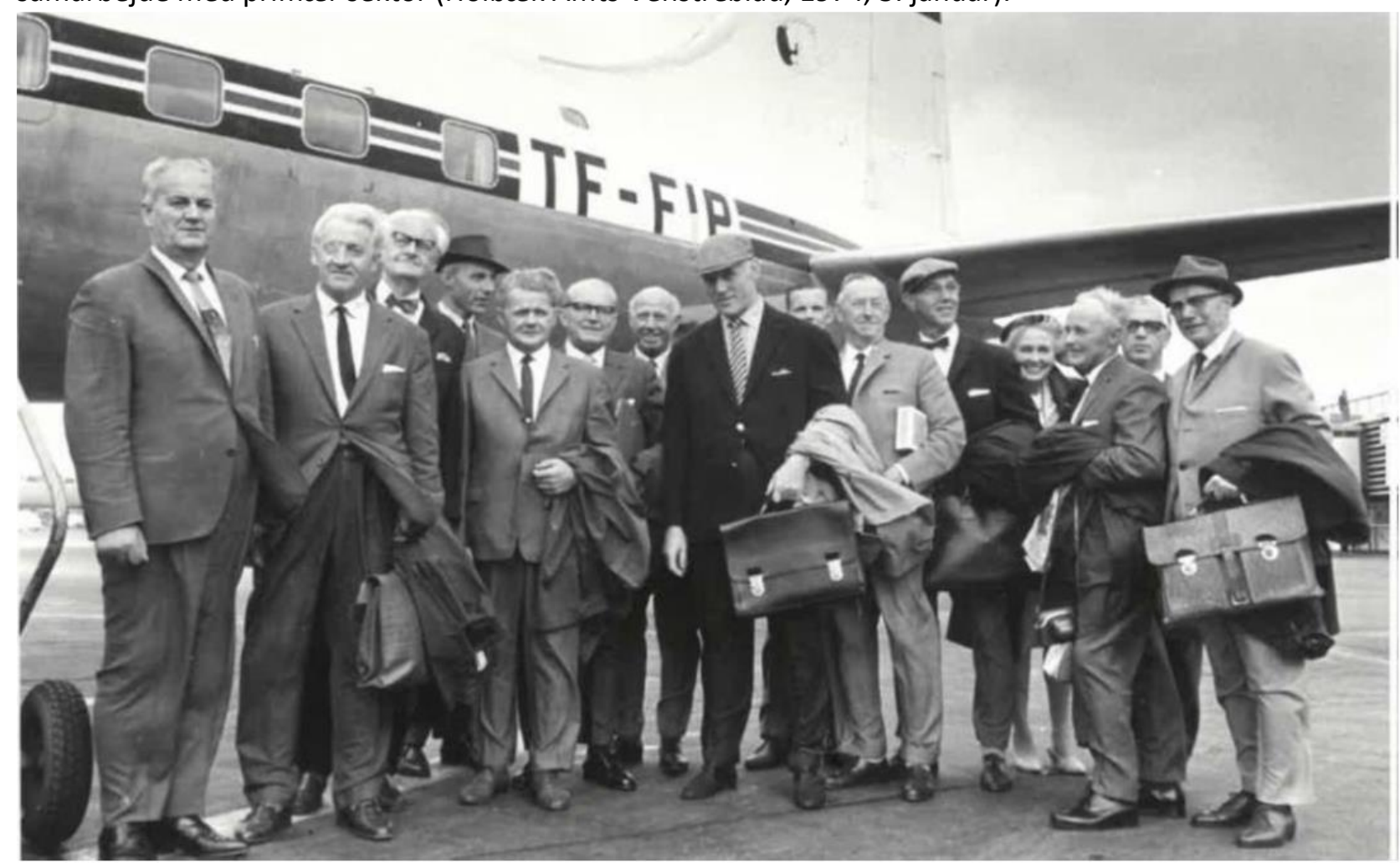

Sygehusbestyrelsens afrejse til England 1968 (Midt i billedet i sort jakkesæt Amtmand Clausen, femte herre fra højre ovekirurg Heiberg, anden herre ra højre administrationschef Dissing Sørensen, kvinden i billedet forstanderinde Hielm Schmidt). Kilde: Konvolut med fotografi og en afrapportering af besøget er fundet $i$ kælderarkivet på Holbæk Sygehus.

I den tredje historiske periode ændres mulighedsbetingelserne sig atter for de tre praksisser på Holbæk Centralsygehus, som går fra at være centralsygehus til akutsygehus.

Holbæk Sygehus' specialiseringspraksis handler om satsning på grenspecialisering på medicinsk afdeling og på generelt ambulant behandling i specialeambulatorier, frem for indlæggelser. Grenspecialiserings satsningen ses ved, at de medicinske afsnit fra anden halvdel af 1990'erne i sygehusets interne telefonbøger i stedet for bogstaver, nu betegnes med det lægefaglige grenspeciale såsom: "Kardiologisk afsnit", "Gastroenterologisk afsnit" og

"Nefrologisk/endokrinologisk afsnit". I den foregående periode havde de i sygehusets oversigter stået som fire medicinske afdelinger, i modsætning til de kirurgiske afdelinger, som var opdelt med reference til de kirurgiske grenspecialer. Vægtningen af de medicinske grenspecialer forstærkes af, at medicinsk afdelingsledelse i 1997 beslutter, at alle de medicinske læger fremadrettet skal tilknyttes et specialafsnit. Tidligere, havde det kun været fem overlæger, som var fast tilknyttet hver deres specialeafsnit, mens resten af lægegruppen "svævede frit rundt i systemet". Tiltaget handler om en stræben efter kontinuitet for både læger og patienter, idet det ikke er unormalt, at 15-20 læger går 
stuegang på samme afsnit i løbet af en måned (Faarvang \& Larsen, 1997). Hermed skabes mulighedsbetingelser for overhovedet at tale om at flytte patienter mellem specialafsnit afhængigt af deres sygdom, idet det førhen havde været af mindre betydning, da lægerne gik stuegang på skift på alle de medicinske afsnit. Der er i hele perioden frem til i dag pres på de medicinske afsnit og for at udligne belægningen, bliver det legitimt, at det er de almen medicinske patienter, typisk de gamle, som flyttes rundt. Den stigende dyrkelse af specialiseringen af de medicinske afsnit betyder, at de sundhedsprofessionelle i stigende grad sondrer mellem specialepatienter og de almene medicinske patienter og anvender italesættelser som: "Det er ikke vores patient!" (Dybbro, 2009). De gamle skabes med udviklingen af specialiseringspraksissen som specialeløse, idet de tilhører ingen og alle de medicinske afsnit.

Sygehusets styringspraksis består af interpellation via professionalisering, specialisering samt nye styringsværktøjer. Sidstnævnte vinder for alvor fodfæste sidst i perioden. Der sker en professionalisering af flere faggrupper i takt med, at sygehusets praksis bliver mere avanceret. Eksempelvis opkvalificeres sygehjælperne til social- og sundhedsassistenter (Vallgårda \& Krasnik, 2016, s. 229). Der sker en stigende specialisering, særligt blandt sygeplejerskerne, hvilket ses i fremkomsten af "specialesygeplejersker", der overtager opgaver inden for specialerne, som lægerne tidligere har varetaget. I 1999 overtager sygeplejersker i lunge-allergiambulatoriet optagelse af patientens anamnese (Centralsygehuset i Holbæk, 1999). I 00'erne opstår i Vestsjællands Amt en ny uddannelse som behandlersygeplejersker, som overtager skadestuehenvendelserne i de nyoprettede skadeklinikker (Leick, 2003). I 00'erne oprettes en sygeplejebaseret hypertensionsklinik, hvor sygeplejersker overtager justeringen af patienternes medicinske behandling (Simper m.fl., 2009). Nye styringsværktøjer fra New Public Management-skuffen kommer til og skal bidrage til effektiv udnyttelse af sygehusets ressourcer og kapacitet. Det handler om handlingsanvisende værktøjer, der bidrager til, at de sundhedsprofessionelle foretager standardiserede unders $\varnothing$ gelse, pleje og behandling af patienterne, hvilket sikrer effektiv ressourceudnyttelse og kvalitet. Det er f.eks. "triage", som er en måde hvorpå patienterne vurderes i forhold til hvor hurtigt, at de bør tilses af en læge (Steenberger, 2009). Det er også et basalt observationsskema (BOS), som er en måde at identificere udviklingen af kritisk sygdom hos patienterne, baseret på måling af deres vejrtrækning, iltmætning, temperatur, blodtryk, puls og bevidsthedsniveau, og som foreskriver særlige handlinger. Det er tillige tryksårscreening, som er en vurdering af patienternes risiko for udvikling af tryksår (Region Sjælland, 2012). Der sker endvidere en digitalisering af lægejournal og sygeplejekardex, hvilket er muliggjort af forrige periodes EDB-implementeringen, som administrationschef Dissing Sørensen allerede dengang så store potentialer i. Med de nye styringsværktøjer så som målinger, scoringer, screeninger og afkrydsninger i de nye digitale platforme og i bestræbelserne på at risikovurdere, sygdomsforebygge og handlingsanvise skabes de gamle som objektive og målbare data, der ikke levner plads til deres livshistorie, hvorfor de gamle gøres historieløse.

Holbæk Sygehus' praksis for gamle patienter er i denne periode optaget af udviklingen af den geriatriske praksis og på styrkelse af samarbejdet med primær sektor. Udviklingen af den geriatriske praksis kommer til udtryk ved, at Holbæk Centralsygehus i 1996 får et tværfagligt team "geriatrisk team" bestående af en fysioterapeut, en ergoterapeut, en sygeplejerske, en geriatrisk overlæge og en lægesekretær, som skal: "sikre den bedst mulige behandling og det mest hensigtsmæssige indlæggelsesforl øb for gamle mennesker, indlagt i medicinsk afdeling" (Centralsygehuset i Holbæk, 1996). Styrkelse af samarbejdet med primær sektor ses ved implementeringen i 1997 af en ny samarbejdsmodel mellem centralsygehuset, Holbæk Kommune og de praktiserende læger med titlen: "Patienten mellem to stole". Modellen har til hensigt at styrke samarbejdet omkring udskrivelse af gamle mennesker med "aldersbetinget funktionsnedsættelse", så bl.a. indlæggelsestiden bliver reduceret (Centralsygehuset i Holbæk, 1997). Hvor den geriatriske overlæge Hjermind i sidste periode havde fokus på, at de gamle kunne komme i klemme mellem de 
lægefaglige specialer, er det nye tiltags fokus mere overgangen mellem sygehus- og primær sektor. Sygehusets optagethed af at få udskrevet de gamle til primær sektor kan ses som led i den ændrede opgavefordeling mellem sygehuse og kommuner på nationalt plan i perioden. En ændret opgavefordeling, der bliver særlig tydelig med vedtagelse af Strukturreformen i 2007, hvor opgaven med varetagelse af de gamles pleje og også behandling såsom genoptræning bliver til en kommunal opgave (Indenrigs- og Sundhedsministeriet, 2005). Den ændrede opgavevaretagelse mellem sygehuse og kommuner gentages sidenhed i de nationale handleplaner for den gamle medicinske patient (Ministeriet for Sundhed og Forebyggelse, 2011) (Sundheds- og ældreministeriet, 2016). Med den ændrede praksis for de gamle medicinske patienter bliver det selvfølgeligt for de sundhedsprofessionelle i sygehusregi at interessere sig mindre for denne gruppe og at tale om de gamle som en gruppe, der ikke burde være indlagt, men i stedet burde forblive i tilbud i primær sektor. Sygehusets indretning synes ikke befordrende eller egnet til de gamle med deres særlige udfordringer ved sygdom. En af de interviewede sygeplejersker udtaler:

Altså man håber jo, at de kommer et sted hen, hvor de ikke skal ligge på gangen, og hvor der ikke er for meget uro og alt sådan noget. Det er da en udfordring for alle ældre mennesker at komme på sygehuset ikke. Det er jo et helvede for dem, for at sige det mildt

og "Når du er udfordret dels på din alder, dels på din mobilitet, dels på din hjerne måske pga. sygdom eller demens eller et eller andet, så er du jo helt hægtet af i sådan et miljø (sygehusmiljø)" (Koordinerende sygeplejerske A). Med den ændrede praksis for gamle medicinske patienter bliver de gamle gjort til interesseløse for de sundhedsprofessionelle.

Denne historisk følgen af muligheds- og fremkomstbetingelser for de tre praksisser på Holbæk Sygehus afdækker, hvordan der fra 1990'erne og frem sker ændringer inden for praksisserne på en måde, som skaber de gamle medicinske patienter som specialeløse, historieløse og interessel øse. Den historiske afdækning viser, at praksisserne hver især bliver ændret i bestræbelserne på at forbedre, men at kombinationen af de tre praksisser fører til en udfordring for gruppen af gamles indlæggelsesforløb i dag.

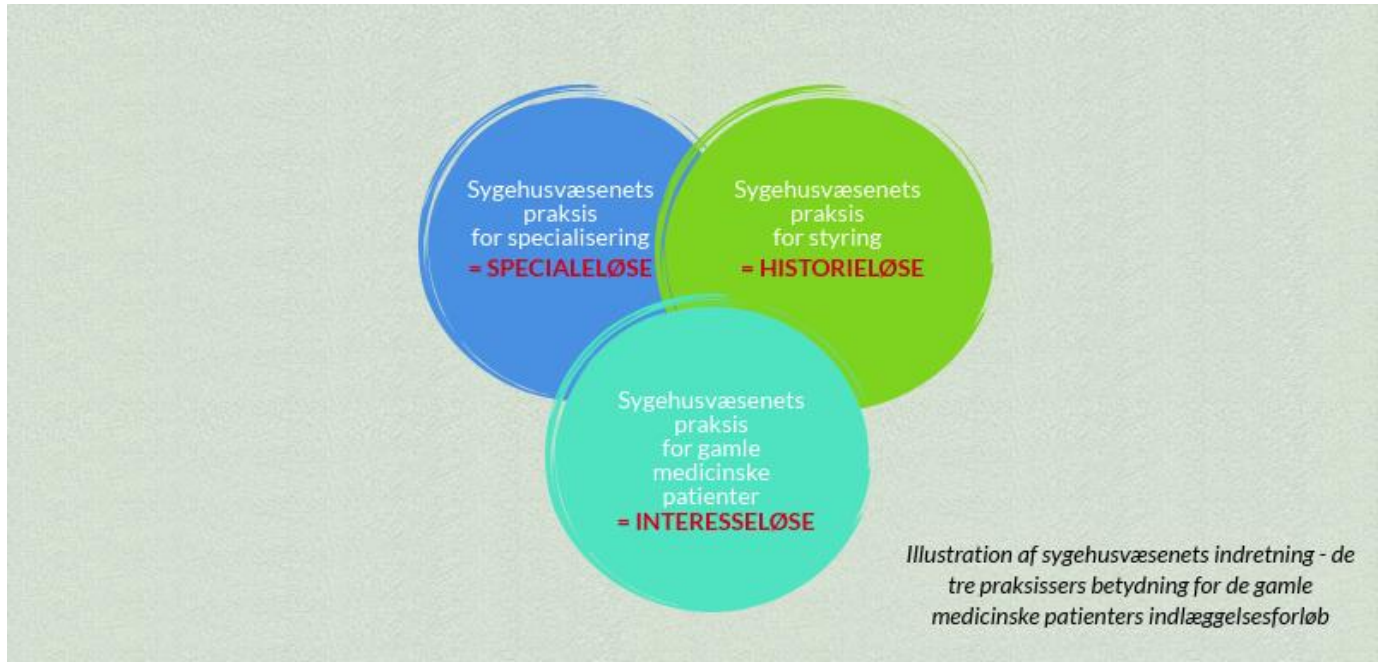

\section{Paradigmeskift}

Det historiske tilbageblik gjorde det endvidere muligt at opnå indblik i paradigmeskift. I det her tilfælde i paradigmet i sygehusvæsenets praksis over tid og på en måde, der styrker den nutidige sundhedsfaglige problemstilling omkring de gamle medicinske patienter.

Følger vi atter de tre praksisser tilbage i tiden, så stræbte Holbæk Amtssygehus i den første historiske periode efter, det som filosof Uffe Juul Jensen betegner som "en sygdomsorienteret 
praksis", der tager afsæt i en biomedicinsk sygdomsopfattelse, hvor sygdom betragtes som en afgrænset "biologisk funktionsfejl", der kan behandles (Juul Jensen, 1986, s. 47). Det kom til udtryk i den daværende professor Flindts opg $\varnothing$ r med sygehusets svine- og hønsehold, som han ikke mente hørte sig til på et sygehus. Han skrev i en klageskrivelse til Amtsrådet følgende:

Det er urimeligt, at der findes Svinehold i Anstalten. Alt, hvad der kan fordærve Luften og Jordbunden i og omkring Sygehuset, bør for enhver Pris undgaas (...) Hvorvel et større Hønsehold ikke kan blot tilnærmelsesvis foraarsage hygiejniske Ulemper, der kan sammenlignes med de af Svineholdet flydende, maa det dog anses for mindre vel betænkt, som sket er, at anbringe Hønsehuset umiddelbart op ad Sygehusbygningerne, hvorved Renheden af den Luft, som ved Ventilationen føres ind i disse, kun kan forringes (Flindt, 1887c).

Den sygdomsorienterede praksis har afsæt i en fragmenteret, specialiseret og biomedicinsk viden. Foucault taler om, at mennesket og patienten med den nye medicinske diskurs blev til det objekt, som sygdommen midlertidigt havde besat. Gennem sit kliniske blik, "den retmæssige indehaver af sandheden", lokaliserede lægen sygdommen hos patienten og subjektet, som derved blev gjort til unders $\varnothing$ gelsesgenstand og objekt for lægens blik (Foucault, 2000b, s. 29, 38, 102). Lægens kliniske blik på amtssygehuset var således rettet mod at behandle den biologiske funktionsfejl, mens patienten blev til objektet for lægens blik. Objektgørelsen af patienterne bliver tydelig på fotografier af patientbehandling og stuegang på amtssygehuset. På det ene fotografi er lægen i færd med at behandle en patient, som passivt lader sig fotografere liggende i sengen med blottede kønsorganer. På det andet fotografi ligger patienten på samme måde passiv og afventende.
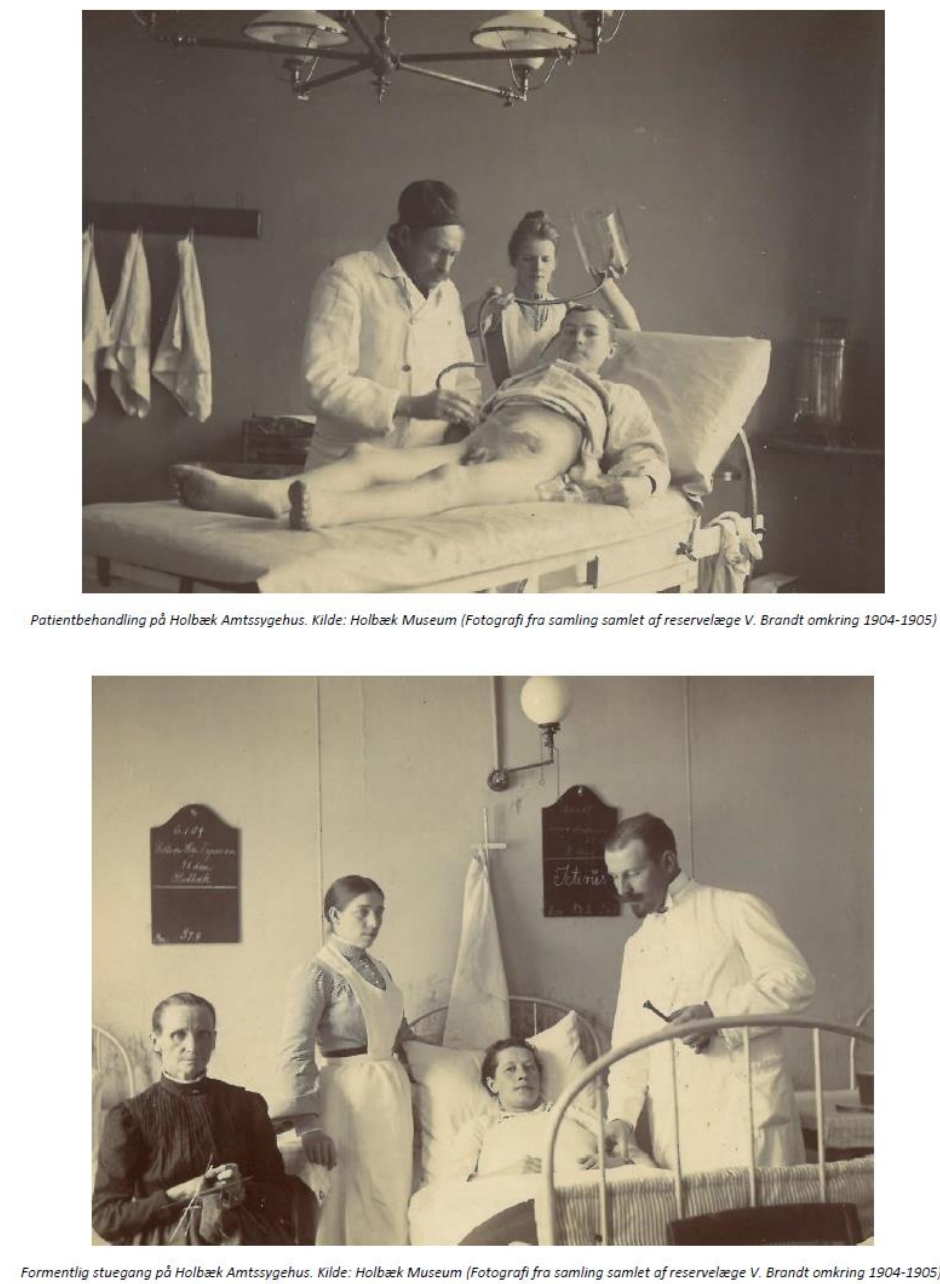
I den anden historiske periode skete et skift i det herskende paradigme i sygehusets praksis, som udviklede sig i retning af det, som Juul Jensen betegner som "en situationsorienteret praksis" med fokus på patientens samlede situation og med målet om livskvalitet for den enkelte (Juul Jensen, 1986, s. 41-42). Centralsygehusets praksis havde karakter af et helhedsorienteret blik på patienten, hvilket gik igen i flere af centralhusets overlæger og sygeplejerskers italesættelser. Ledende overlæge Hansen sagde om patientbehandlingen: "Vi maa ikke glemme, at mennesker har baade legeme og sjæl, og begge dele maa der tages hensyn til" (Holbæk Amtstidende, 1951, 20. januar). Mens overlæge Thomsen udtrykte det på denne måde: "man vurderer hvert sygdomstilfælde ud fra en helhedsbetragtning af patienten, og ikke bare medicinsk ogsaa at man fors $\varnothing$ ger at forstaa patienten som medmenneske" (Holbæk Amts Venstreblad, 1960, 30. december). Forstanderinde Hielm Schmidt sagde: "Patienter kommer som paa samlebaand. Den legemlig behandling er i orden, men hvad med den sjælelige? Her bør sættes mere ind. Man maa ikke glemme det menneskelige" (Holbæk Amts Venstreblad, 1952, 5. april). Sygehusets tiltagende specialisering var samtidig en særlig udfordring, som lægerne måtte være særlig opmærksom på. Overkirurg Bindslev udtrykte det således: "Det er mennesker vi behandler, ikke organer, og vi maa gør alt for, at patienterne ikke bliver et nummer og ikke føler sig som et nummer" (Holbæk Amtstidende, 1960, 3. februar). Den situationsorienterede praksis kom til udtryk i centralsygehusets ambition om at skulle fungere som hjem og hotel for patienterne. Ledende overkirurg Heiberg udtalte: "Vi skulle ogsaa gerne komme dertil, at et sygehus af patienterne føles som et hjem, thi ingen har vel haardere brug for et kærligt hjem end netop de syge" (Holbæk Amts Venstreblad, 1949, 20. juni) og "det er vort ønske, at sygehusene (i Holbæk Amt) maa væres saa gode som hoteller med hjemlige hygge" (Holbæk Amtstidende, 1950, 13. maj). Det tyder på, at ambitionen lykkedes, idet en journalist, som besøgte centralsygehuset, blandet andet skrev: "det er saa moderne indrettet, at man faktisk har indtryk af, at det er et bedre hotel, hvor man kan tage ind, naar man føler sig syg" (Ekstrabladet, 1952, 13. oktober). I 1960'erne kom cafeteria og frisørsalon til patienterne (Holbæk Amts Venstreblad, 1967, 21. marts), som kunne ses som i tråd med ambitionen om sygehuset som hjem og hotel. Der var ingen grænser for, hvad centralsygehuset tog sig af. En ældre mandlig patient berettede om, hvordan han grundet indlæggelse ikke havde haft mulighed for at deltage i datterens bryllup. Afdelingen under ledelse af overkirurg Heiberg arrangerede derfor til den ældre herres store glæde og overraskelse, at brudeparret kom og dansede brudevalsen på afdelingen, hvor han var indlagt (Holbæk Amtstidende, 1952, 28. oktober). Der blev tilstræbt at holde på patienterne lidt længere for at sikre, at de var friske. Heiberg udtalte: "En 'normal' patient faktisk klar til hjemsendelse fra sygehuset, men patienten er ikke arbejdsdygtig (...) Derfor beholder vi patienterne lidt længere, men er dog nu nede paa gennemsnitlig 16 mod før 21 dage for hver kirurgisk patient" (Holbæk Amts Venstreblad, 1949, 20. juni). Heiberg tog tillige initiativ til morgengymnastik for patienterne (Holbæk Amts Venstreblad, 1952, 21. juni).

I den sidste historiske periode kan atter iagttages et paradigmeskift i sygehusvæsnets praksis, som fra at have indtaget en situationsorienteret praksis vender tilbage til en mere sygdomsorienteret praksis, som fokuserer på behandling baseret på specialiseret, fragmenteret, biomedicinske viden. Flere af de interviewede lægers fokus i dag er deres speciale. En overlæge siger: "Jeg må koncentrere mig om det kardiologiske, som det folk kommer for, og få løst deres kardiologiske problem. Det synes jeg er det vigtigste for mig, der må man være lidt skruppelløs og skære igennem" (Overlæge H). En anden overlæge siger om de gamle medicinske patienter: "så skal vi passe plejehjemsbeboer, mens der er 800 ekkoer (hjertescanninger), som venter på os" (Overlæge/ feltarbejdet). Det kommer også til udtryk ved, at sygeplejerskerne, der tidligere har haft plejen som fokus, bevæger sig ind på lægernes domæne, hvor de bliver "specialesygeplejersker" i ambulatorier og akutfunktioner. Sygehuset sigter endvidere efter at omdanne mest muligt af patientbehandlingen til ambulant virksomhed. Der er eksempelvis i 1990'erne kommet medicinske specialeambulatorier til, som udbygges med specialedagafsnit for at aflaste den stigende belastning på de medicinske afsnit 
(Faarvang \& Larsen, 1997). Udbygningen af den ambulante praksis indikerer, at sygehuset i lighed med den nationale sygehuspraksis prioriterer mere ambulant behandling, og at sygehuset er vendt tilbage til fokus på behandling frem for pleje. Denne prioritering af den ambulante behandling fortsætter og i driftsaftalen fra 2013 står om sygehusets indsatser: "En anden indsats er, et fokus på om nogle indlæggelser kan omlægges til ambulante forl $\varnothing b "$ (Region Sjælland, 2013). Den ændrede patientpraksis med at afgrænse patientpraksis til udelukkende at omhandle behandling kan også ses ved, at fris $\varnothing$ r og cafeteria, som blev indført i 1960'erne, bliver udfaset og ændrer form. Frisøren forsvinder i 1990'erne, idet den efter 1995 ikke længere fremgår af den interne telefonbog, mens cafeteriaet i starten af 00'erne bliver erstattet af en kiosk og borde på gangen i sygehusets forhal. Det oprindelige patientcafeteria bliver i stedet til en personalekantine, hvilket den fortsat fungerer som i dag. Fris $\varnothing$ r og cafeteria repræsenter Heibergs vision om Holbæk Sygehus som et hjem eller hotel for patienterne, hvor de hellere skulle blive en ekstra dag, mens kiosk og borde associerer kortere ophold i tråd med sygehusets agenda om i dag primært at være behandlingssted med korte indlæggelser og ambulante forløb. De nye styringsværktøjer støtter op om dette paradigme, idet f.eks. standarder også er baseret på specialisereret, fragmenteret og målbar viden.

Det historiske tilbageblik har tydeliggjort, hvordan paradigmet i sygehusets praksis har vekslet mellem en situationsorienteret social praksis og en sygdomsorienteret behandlingspraksis. I dag synes den sygdomsorienterede behandlingspraksis med fokus på specialiseret og fragmenteret viden at råde, hvilket underst $\varnothing$ tter problemstillingen omkring de gamle patienters indlæggelsesforl $\emptyset b$. Deres indlæggelsesforl $\emptyset \mathrm{b}$ set $\mathrm{i}$ et geriatrisk specialeperspektiv tydeligg $\varnothing r$, at sygdom og indlæggelsen giver dem særlige vilkår og udfordringer. Det drejer sig om komplekse, rodede og anderledes sygdomsbilleder med muligheden for udvikling af olympiadesyndromet, konfusion og delir (Schroll, 1983) (Andersen-Ranberg \& Matzen, 2016). Vilkår og udfordringer som skaber behov for sammentænkning af fysiske, psykiske og sociale aspekter i indsatsen, der fordrer ikke kun behandling men også en helhedsorienteret pleje og omsorg.

\section{Forandringer over tid}

Den historiske feltarbejde gjorde det også muligt at indsamle empirisk materiale, som afdækkede forandringer over tid. I det her tilfælde, hvordan sygeplejerskens rolle og funktion har forandret sig på en måde, som bidrager til en indretning, der ikke understøtter de behov gamle patienter har i forbindelse med indlæggelse.

I den første historiske periode fungerede sygeplejersken som assisterende og omsorgsgivende. Amtssygehuset skabte mulighed for en professionel husmoderudgave, hvor kvinder med virke som sygeplejersker fik mulighed for professionel husholdning og omsorgsudøvelse. Derigennem opnåede de en samfundsmæssig legitimitet, status og position. Sygeplejerskegerningen gav en legitimitet for ugifte kvinder fra de bedre samfundslag. Afdelingssygeplejerskerne på amtssygehuset var frøkner og d $\varnothing$ tre af en skoleinspektør, en lærer, en slagter, en skovløber, en boelsmand og flere gårdejere (Kirkeskov \& Larsen, 1933, s. 101). Sygeplejerskerne fik, som det fremgår af de to fotografier af en patientbehandling og en stuegang, rollen som lægens assistent og hjælper. På det ene fotografi holder sygeplejersken det medicinske udstyr, mens lægen udfører behandlingen. På det andet står sygeplejersken klar til at assistere ved patientens side, mens lægen måler patientens puls.

I den anden historiske periode virkede sygeplejersken fortsat som assisterende og omsorgsgivende. Et eksempel på sygeplejerskens assisterende funktion er fotografiet af sygeplejerske Larsen, der jf. overkirurg Heibergs ordination gennemførte morgengymnastik for indlagte patienter (Ekstrabladet, 1952, 13. oktober). Sygeplejersken som omsorgsgivende med vægt på uegennyttighed og næstekærlighed ses i forstanderinde Hielm Schmidts tale ved sin afsked, hvor hun sagde: "Sygeplejerskers fremtidige arbejde vil mere end nogensinde kræve menneskekærlighed i 
et kompliceret teknokrati" (Holbæk Amts Venstreblad, 1969, 12. juli). Afdelingssygeplejersken, frøken Jacobsen udtalte endvidere om at holde jul væk fra familien:

Der er saa meget man maa tænke paa! Først og fremmest patienterne, der da er bundet til sengen - der ikke kan smutte rundt omkring og besøge alle afdelingerne juleaften. Dem har jeg ondt af. Dem er det synd. Ikke mig" og "Man hjælper andre. Man hjælper dem, der trænger og det mærker man. Det er en god og rar fornemmelse (Holbæk Amtstidende, 1959, 24. december).

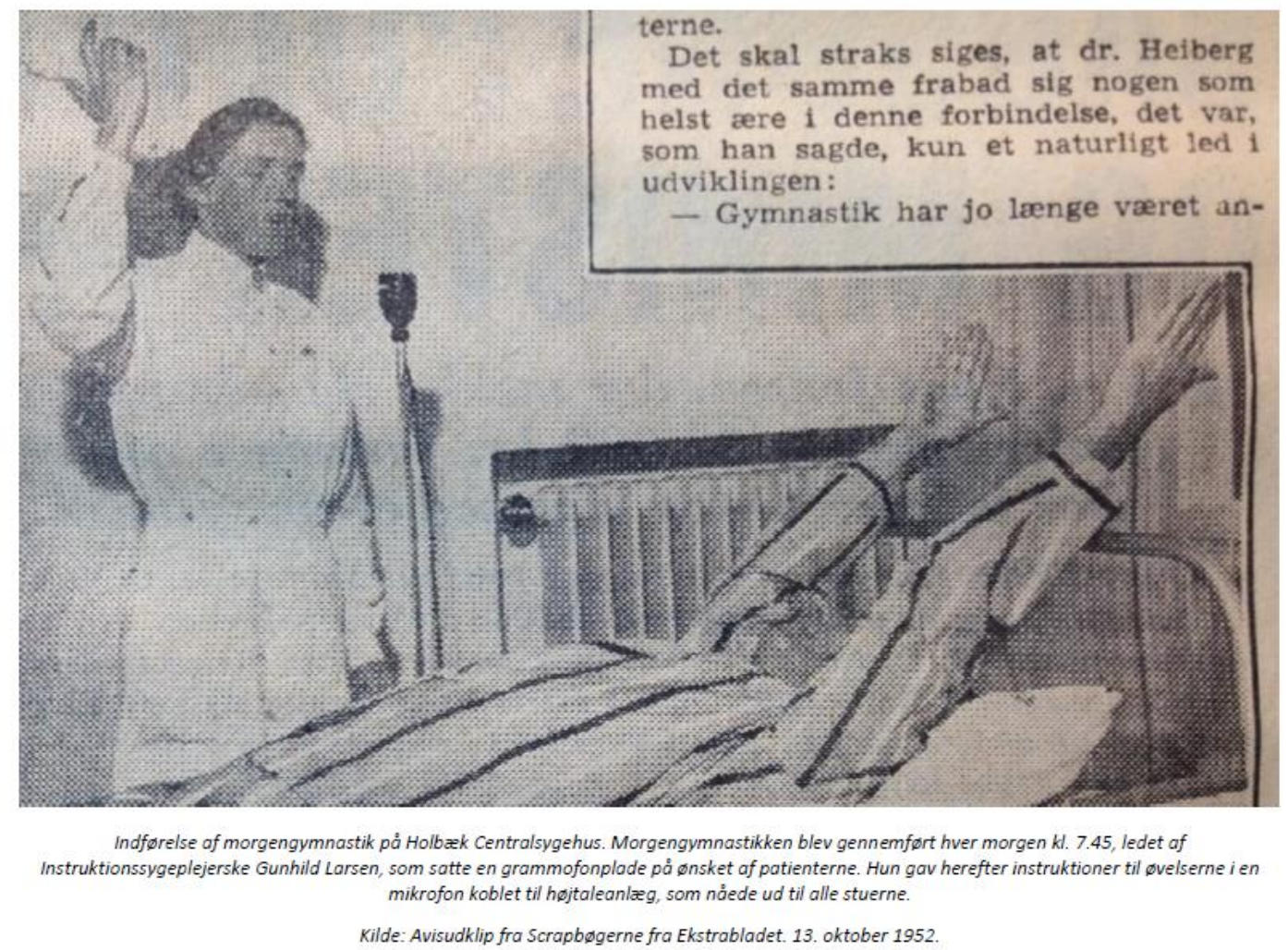

Som noget nyt var sygeplejerskerne ledende af sygeplejen på forskellige niveauer. Der var på centralsygehuset kommet en forstanderinde, som ledede sygeplejen på det overordnede niveau. Centralsygehusets forstanderinde, som kan ses som en erstatning for tidligere tiders oversygeplejerske, fik ansvaret for en gradvist større plejegruppe. Oversygeplejersken havde omkring 1930 ansvar for fire afdelingssygeplejersker, fire assistenter og 21 elever, mens Hielm Schmidt i 1969, som det fremgår af fotografi, havde 18 afdelingssygeplejersker og et ukendt antal sygeplejersker og sygehjælpere under sig. Den efterfølgende forstanderinde Storm Hansen havde i 1974 ansvaret for cirka 550 sygeplejersker og sygehjælpere (Sjællands Tidende, 1974, 19. december). På de enkelte afdelinger blev der desuden fra 1970'erne afholdt morgenkonference, jf. fotografi af morgenkonference, hvor en sygeplejerske ledede og tilrettelagde den daglige pleje og omsorg. 


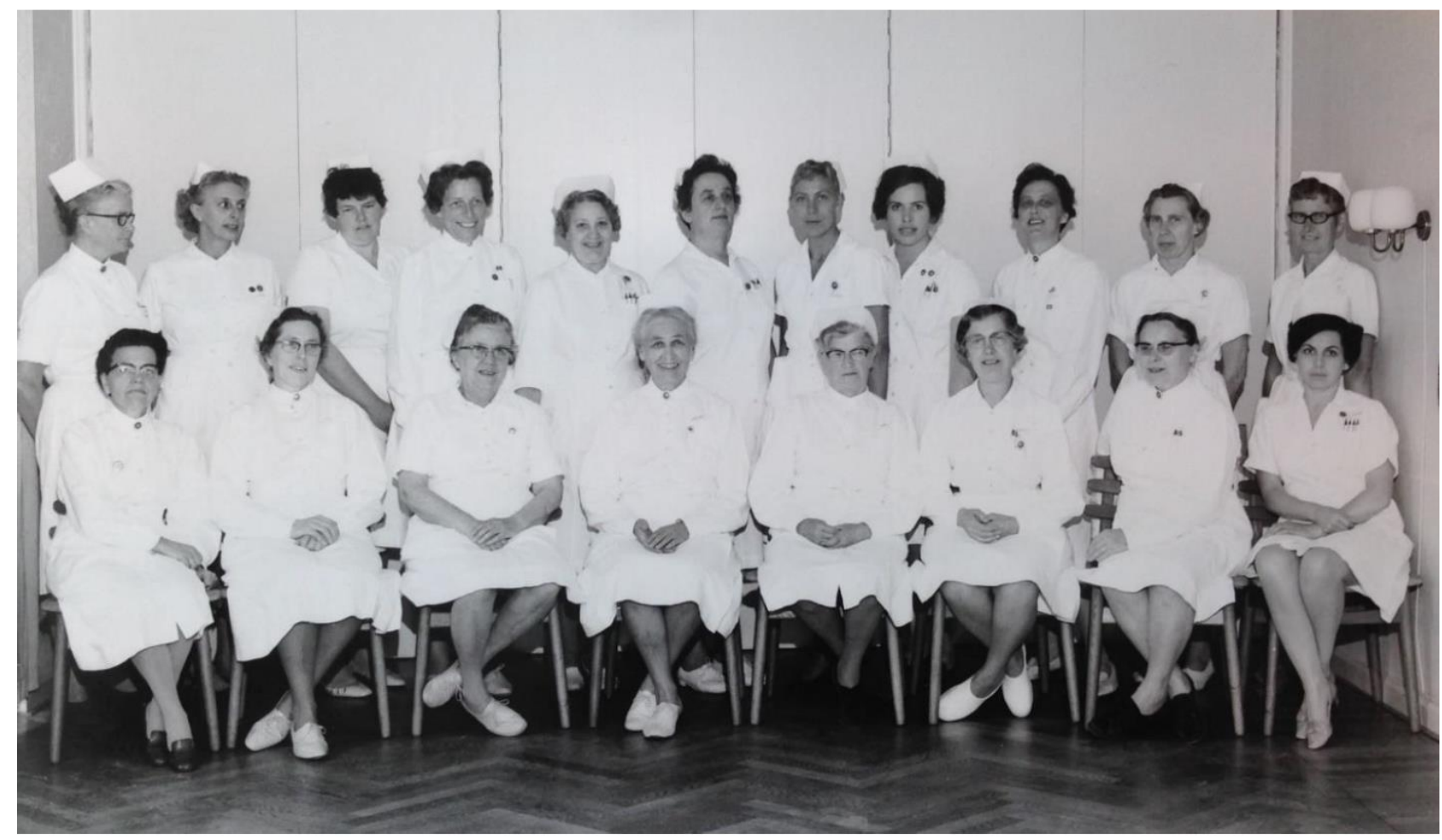

Fotografi af sygehusets afdelingssygeplejersker og forstanderinde med teksten "I anledning afforstanderinde frøken I. Hielm Schmidts afsked pr. 1. september 1969". Kilde: Kælderarkiv på Holbæk Sygehus.

I den tredje historiske periode synes sygeplejerskens rolle fortsat at være af ledende karakter, men nu også behandlingsgivende og forskende. Fra 1990erne bliver forstanderinden erstattet af en chefsygeplejerske, som senere bliver til en sygeplejefaglig vicedirektør. Sidstnævnte udg $\varnothing r$ i dag sammen med en lægelige vicedirektør og en sygehusdirektør sygehusets ledelse. Sygeplejerskerne på afdelingerne er ikke kun ledende at sygeplejen, men af udnyttelse af sygehusets samlede kapacitet, idet det er en sygeplejerske, som står i spidsen for de daglige kapacitetskonferencer.

Sygeplejerskerne overtager i denne periode dele af lægernes tidligere domæne ved som specialesygeplejersker og behandlersygeplejersker selvstændigt at vurdere og behandle forskellige patientgrupper. Nogle læger oplever med dette skift i sygeplejerskernes praksis fra at varetage pleje og omsorg til behandling, at: "nu taler vi samme sprog" (Andersen, 2005). Andre oplever at mangle tidligere tiders sygeplejerske og læge-sygeplejerske-relation. En overlæge siger: "Jeg mangler den der kompetente ekspertsygeplejerske, som ved det hele, altså hvor vi bare behøver at se på hinanden" (Overlæge R). Sygeplejersker begynder som noget nyt at forske, i lighed med lægerne, inden for eksempelvis tværsektorielle problematikker, som er del af regionens forskningsforpligtelse jf.

Sundhedsloven. Region Sjælland har således egen forskningsstrategi, hvori der satses på: "at fremme forskning inden for MVU-området" og "tværsektorielle forskning med kommuner" (Region Sjælland, 2015). MVU-området refererer til Mellemlang Videregående Uddannelser, hvorunder sygeplejerskerne indgår. I 2016 indleverer og siden forsvarer den første sygeplejerske således sin ph.d.-afhandling udgående fra Holbæk Sygehus med et projekt omhandlende patientovergange mellem sygehus og primær sektor (Høgsgaard, 2016). Det synes for sygeplejerskerne ubønhørligt slut med tidligere tiders position som "lægens assistent", idet de med de mange nye funktioner gradvist opnår mere indflydelse og magt på sygehuset. Man kan spørge sig selv, hvor sygeplejerskens tidligere rolle som pleje- og omsorgsgivende er forsvundet hen med den udvikling. Begrebet omsorg synes at være udgået af de sundhedsprofessionelles sprogbrug, hvilket kan tolkes som, at det ikke længere er omsorg, der lægges vægt på i udøvelsen af pleje og behandling. Af de 20 interviewede sundhedsprofessionelle italesættes omsorg af en enkelt afdelingssygeplejerske. Hun siger: 
Jeg tror, vi simpelthen er skolet til omsorg i mit fag, omsorg, omsorg, omsorg og når vi lægger fru Jensen ned, vi tror på, at det er godt at ligge ned, når man har fået den her lungebetændelse og uhm..., men vi skal altså mobilisere (Afdelingssygeplejerske A).

Omsorg forbindes her med noget negativt.

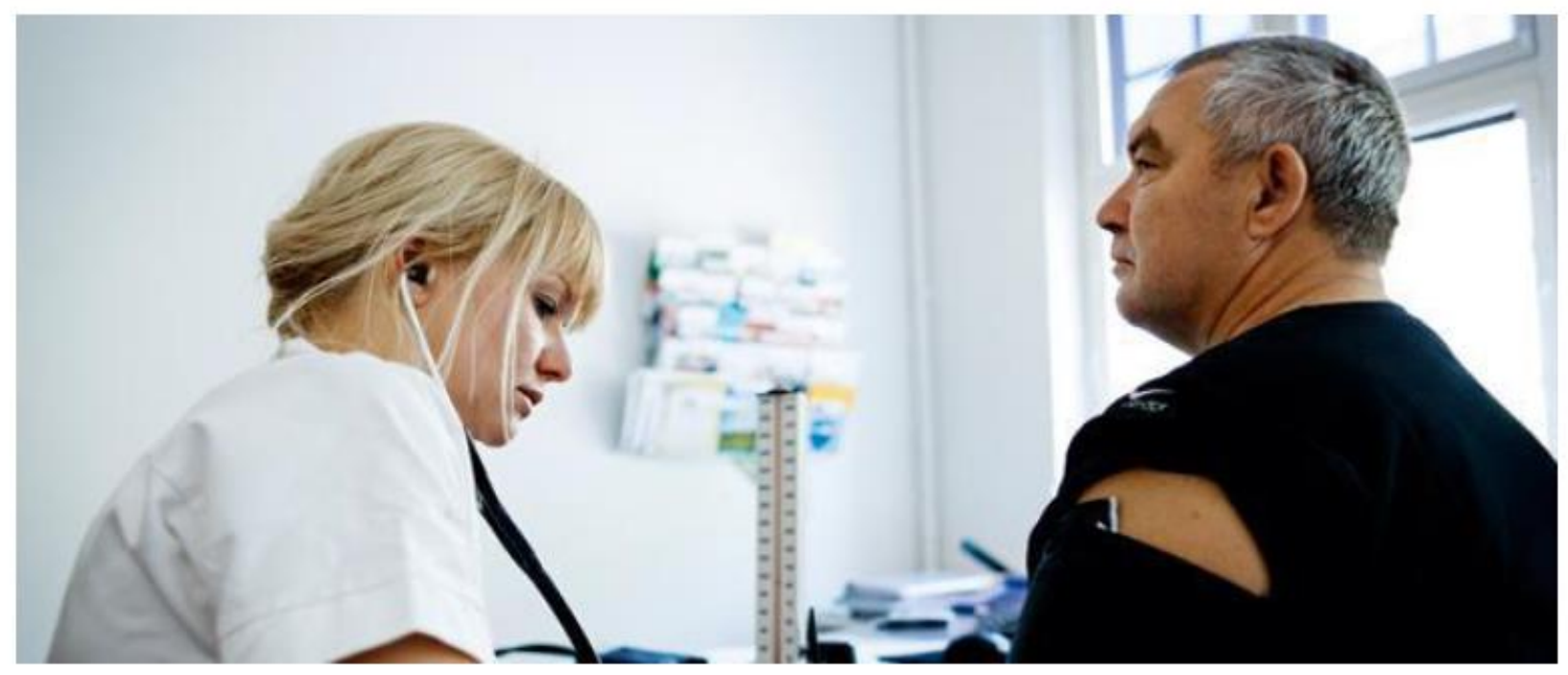

Fotografi fra hypertensionsklinikken på Holbaek Sygehus, hvor sygeplejerske Minja Tobiassen målte en patients blodtryk. Kilde Sygeplejersken (13) 2011

Som ovenfor illustreret, medvirker det historiske feltarbejde til at vise, hvordan sygeplejerskens rolle og funktion har ændret sig fra at være assisterende og omsorgsgivende til at være ledende, forskende og behandlingsgivende. En udvikling som for sygeplejeprofessionen muligvis kan synes positiv, men for de gamle kan være en udfordring med deres behov for pleje og omsorg af fysisk, psykisk og social karakter i forbindelse med indlæggelse (Schroll, 1983).

\section{Variationsbredden}

Den historiske udforskning har også afdækket den store variationsbredde i de måder, at sygehusvæsenet har indrettet sig gennem historien. Variationsbredden viser, at ikke alle tanker er nye, hvilket synes vigtigt i nærværende ph.d.-projekt, hvor formålet har været at skabe ny viden og perspektiver, der kan bidrage i praksisudviklingen af sygehusvæsenets indretning, så den i højere grad tilgodeser og underst $\varnothing$ tter de gamles særlige vilkår, udfordringer og behov.

Når udekørende akutteams i dag hædres med kommunale initiativpriser som "den gyldne tråd", som løsning på udfordringen i forhold til indlæggelse og genindlæggelse af gamle medicinske patienter (Dansk Sygeplejeråd, 2018, 19. januar), så viser min forskning at den tanke og løsning ikke er ny. Allerede i 1980'erne afprøvede Holbæk Kommune en udekørende funktion, for at forebygge at gamle mennesker blev indlagt, og som var led i et tværfagligt forskningsprojekt mellem Holbæk Sygehus, Holbæk Kommune og Socialforskningsinstituttet. Holbæk Kommune havde, sammen med Institut for almen og social medicin, taget initiativ til forskningsprojektet, hvor kommunen, $\mathrm{i}$ samarbejde med de praktiserende læger og centralsygehusets geriatriske overlæge Hjermind, unders $\varnothing$ gte +80 -årige gamle mennesker og deres pår $\varnothing$ rendes håndtering af risikosituationer såsom akut sygdom og sygehusudskrivelser (Almind m.fl., 1987). Unders øgelsen, baseret på interview og spørgeskemaer, resulterede i indførsel af en ordning med akut hjemmesygeplejerskeudrykning for gamle i risikosituationer i Holbæk Kommune for at forhindre genindlæggelser og plejehjemsanbringelser. Ordningen var i første omgang et fors $\varnothing \mathrm{g}$ og blev siden gjort permanent (Danske Kommuner, 1984). 


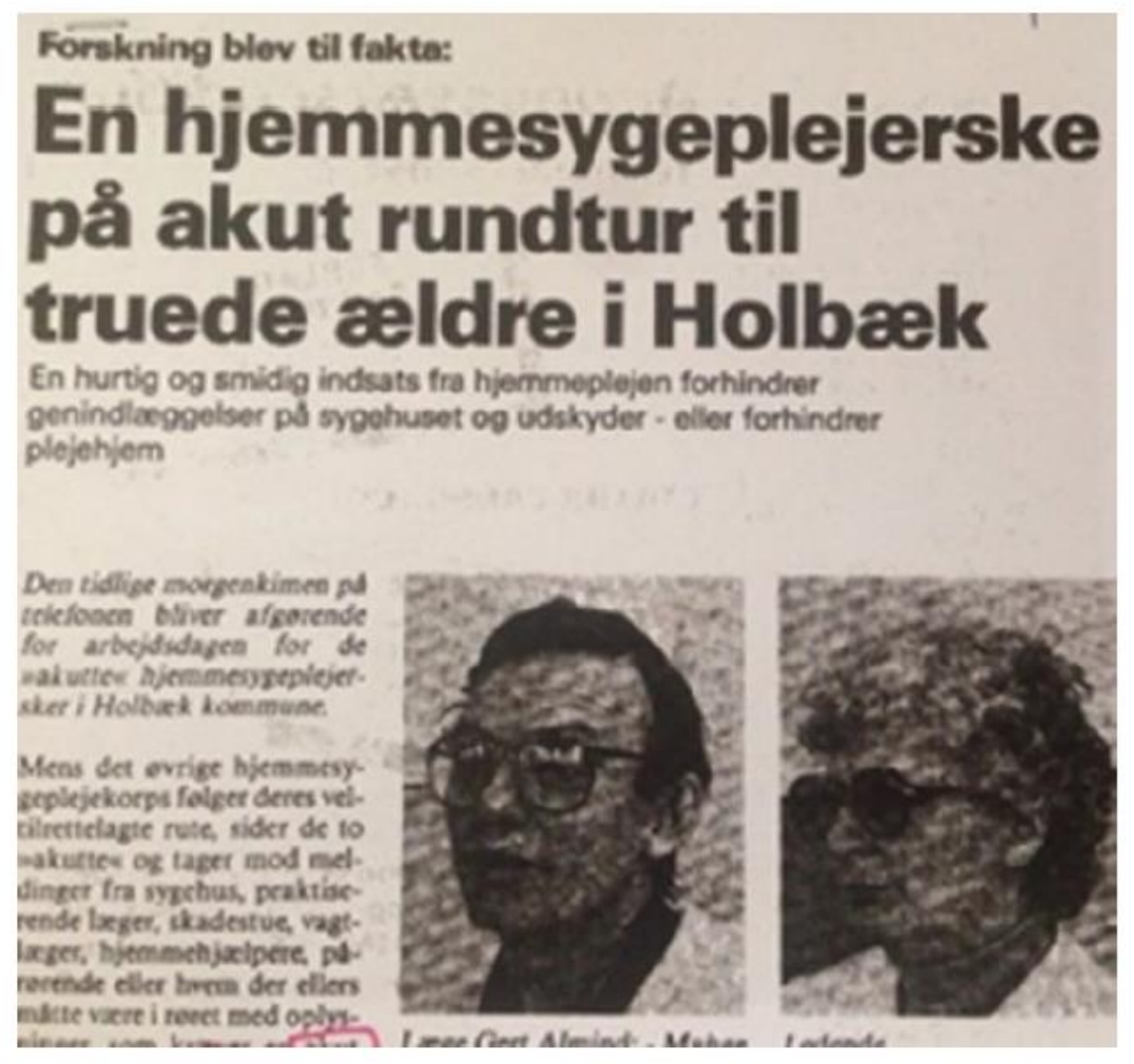

Kilde: Danske Kommuner, 1984, Årg. 15 (24)

Den viden og de erfaringer kan være vigtige og relevante at indtænke i perspektiver og bud på fremtidens indretning af sygehusvæsenet og tilrettelæggelse af gamle menneskers indlæggelsesforløb.

\section{Sammenfatning}

I denne artikel har jeg udfoldet og argumenteret for, hvordan historisk feltarbejde kan bidrage betydningsfuldt både metodisk og analytisk i udforskningen af en nutidige sundhedsfaglig problemstilling.

Metodisk, tilbyder det historiske feltarbejde med sammentænkningen af det etnologiske feltarbejde og den genealogisk tilgang en måde at gribe historisk udforskning an på. Genealogien leverer den overordnede historiske fremgangsmåde, mens feltarbejdet leverer en konkret metode til historisk kildeindsamling. Sidstnævnte foranledigede i nærværende ph.d.-projekt den lokale graven med overraskende fund som et hengemt arkiv med metervis af eksemplarisk historisk kildemateriale, der kan måle sig med eksisterende historisk forskningslitteratur. Mange af Foucaults egne arbejder har tillige karakter af et "lokalt feltarbejde". En anden pointe, jeg har forsøgt at tydeligg øre, er nødvendigheden af "en disciplineret historisk opmærksomhed", for at hindre det historiske feltarbejde i at blive vilkårligt, samt for at kunne navigere i betydelige mængder af historisk materiale.

Analytisk, tilbyder den historiske graven en måde at begribe kompleksiteten i en nutidig sundhedsfaglig problemstilling. I mit tilfælde, bidrager det historiske feltarbejde ikke kun med at afdække de historiske muligheds- og fremkomstbetingelser for den nutidige sundhedsfaglige problemstilling, men også paradigmeskift og forandringer, der styrker problemstillingen. Ligeledes kan det historiske feltarbejde, i tråd med genealogiens ærinde, problematiserer fænomener $\mathrm{i}$ 
nutidige sundhedsfaglige problemstillinger. I mit ph.d.-projekt, problematisering af den i dag selvfølgelige indretning af sygehusvæsenet og tilrettelæggelsen af gamle patienters

indlæggelsesforløb, idet det historiske tilbageblik viser, at udviklingen af indretning og praksisser ikke er naturgiven, men har rødder $\mathrm{i}$ tidligere tiders institutionelle udfordringer. Eksempelvis grenspecialiserings opdelingen af medicinsk afdeling, der udg $\varnothing \mathrm{r}$ en del af udfordringen i de gamles indlæggelsesforl øb i dag, men som blev til i 1990'erne for at skabe kontinuitet for patienter og læger. Når historisk udvikling ikke er naturgivent, åbner det op for at tænke anderledes i fremtiden, for ph.d.-projektets vedkommende i indretningen af sygehus og praksisser. Atter bliver det historiske feltarbejde betydningsfuldt, idet det tydeligg $\varnothing r$, at ikke alle tanker er nye, hvilket er væsentlig viden i bud på fremadrettede perspektiver på sundhedsfaglige problemstillinger.

I $\varnothing$ vrigt, kan historisk feltarbejde skabe uventede bifund, som at baggrunden for tilblivelse af sygehjælperne som profession ikke, som vi i dag antager, handlede om sygeplejerskemangel, men i datiden var tænkt som mobilisering af et beredskab, der kunne træde til i krigs- og katastrofesituationer. Sidstnævnt kan synes betydningsfyldt set i et professionshistorisk perspektiv. 


\section{Referencer}

Almind, G., Holstein, B. E. \& Skovgaard Larsen, B. (1987). Syge gamle mennesker i eget hjem. København: FADL.

Andersen, C. (2005). Alment praktiserende sygeplejersker. Ugeskrift for læger. Årg. 166 (9) 772-776.

Andersen-Ranberg, K. \& Matzen, L. E. (2016). Den geriatriske patient. I: E. A Holm \& F. Rønholt (Red.), Geriatri. København: Munksgaard.

Birch-Jensen, H. (1944). Holbæk Amtssygehus har 100 Aars Jubilæum. Sygehusbladet, 8. Årg. (22), 167-171.

Brinkmann, S. (2015). Etik i en kvalitativ verden. I: S. Brinkmann \& L. Tanggaard (Red.), Kvalitative metoder. En grundbog. København: Hans Reitzels Forlag.

Buus, H. (2001). Sundhedsplejerskeinstitutionens dannelse: en kulturteoretisk og kulturhistorisk analyse af velfærdsstatens embedsværk. København: Museum Tusculanums Forlag.

Centralsygehuset i Holbæk (1996). Geriatriske teams officielle start. Personalebladet (3), 2-3.

Centralsygehuset i Holbæk (1997). "Patienten mellem to stole". Nyt samarbejdsprojekt mellem centralsygehuset, Holbæk Kommune. Personalebladet (3).

Centralsygehuset i Holbæk (1999). Hvad laver sygeplejerskerne i lunge-allergiambulatoriet? Personalebladet (2), 3.

Dansk Sygeplejeråd (2018, 19. januar). Sygehuset kommer hjem til patienten. Ny type akutteam i Esbjerg har modtaget initiativprisen 'Den Gyldne Tråd 2018' for en effektiv brobygningsmodel mellem sygehus og kommune. Hentet fra: https://dsr.dk/politik-og-nyheder/nyhed/sygehusetkommer-hjem-til-patienten

Danske Kommuner (1984). En hjemmesygeplejerske på akut rundtur til truede ældre i Holbæk. Danske kommuner, 15 (24) 22-23.

Det Kongelige Bibliotek (2020). Pligtaflevering. Hentet fra: http://www.pligtaflevering.dk/

Dybbro, L. A. (2009). Det er ikke vores patient! - en etnologisk statsteoretisk analyse og kvalitativ undersøgelse af sygehusvæsenets specialisering og betydningen for patienter, som ikke kan inkluderes ift. denne specialisering (Masterafhandling). Aarhus Universitet.

Ekstrabladet (1952, 13. oktober). Morgengymnastik og ønskekoncerter for hospitalspatienter. Falch, L. A. (2018). "Det er ikke vores patient - en kulturteoretisk og kulturhistorisk analyse af betydningen af sygehusvæsenets indretning for gamle medicinske patienters indlæggelsesforløb med Holbæk Sygehus som eksempel" (Ph.d.-afhandling). Aarhus Universitet. Hentet fra: https://www.researchgate.net/profile/Lisbeth Aaskov Falch/publication/331703706 Det er ikke vores patient -

en kulturteoretisk og kulturhistorisk analyse af betydningen af sygehusvaesenets indretning for gamle medicinske patienters indlaeggelsesforlob med Holbaek Sygehus som ekse/links $/ 5$ c88e11aa6fdcc38174fd387/Det-er-ikke-vores-patient-en-kulturteoretisk-og-kulturhistorisk-analyseaf-betydningen-af-sygehusvaesenets-indretning-for-gamle-medicinske-patientersindlaeggelsesforlob-med-Holbaek-Sygehus-som-ekse.pdf

Faarvang, K. L. \& Larsen, K. (1997). Fremtidens lægearbejde er kommet til Holbæk. Ugeskrift for læger. Årg. 159 (40), 5996-6001.

Flindt, N. (1887a). Bemærkninger om de hygiejniske Forhold i Amts Sygehus ved Holbæk (Uddrag). Sygehuset - Informationsblad for personalet ved sygehusvæsenet i Holbæk, August 1973(2).

Flindt, N. (1887b). Bemærkninger om de hygiejniske Forhold i Amts Sygehus ved Holbæk (Uddrag). Sygehuset - Informationsblad for personalet ved sygehusvæsenet i Holbæk, Februar 1974 (2).

Flindt, N. (1887c). Bemærkninger om de hygiejniske Forhold i Amts Sygehus ved Holbæk (Uddrag). Sygehuset-Informationsblad for personalet ved sygehusvæsenet i Holbæk, April 1975 (16). 
Foucault, M. (1977). Nietzsche, Genealogy, History. I: D. F. Bouchard (Ed.), Language, CounterMemory, Practice: Selected Essays and Interviews. Ithaca, New York: Cornell University Press. Foucault, M. (1988). Technologies of the Self. I: L. H. Martin, H. Gutman, P. H. Hutton (Eds.), Technologies of the Self. A Seminar with Michel Foucault. London: Tavistock Publications. Foucault, M. (2000a). The Subject and Power. I: J. D. Faubion (Ed.), Power. The Essential Works of Foucault 1954-1984. Volume 3. New York: The New Press.

Foucault, M. (2000b). Klinikkens fødsel. København: Hans Reitzels Forlag. Foucault, M. (2001). Talens forfatning. København: Hans Reitzels Forlag. Gustavsson, B. (2001). Vidensfilosofi. Aarhus: Forlaget Klim.

Harpøth, I. T. (1944). Amtssygehuset i Holbæk. Et hundrede Aars Jubilæum. Ugeskrift for læger, 106 Årg. (42), 1049-1051.

Hastrup, K. (2010). Topografiske infiltrationer: Udfordringer til en realistisk samfundsvidenskab. Nordisk udkast. Årg. 38 (1 \& 2), 5-16.

Hastrup, K. (2015). Feltarbejde. I: S. Brinkmann \& L. Tanggaard (Red.), Kvalitative metoder. En grundbog. København: Hans Reitzels Forlag.

Heede, D. (2007). Det tomme menneske - introduktion til Michel Foucault. København: Museum Tusculanums Forlag.

Hertz, M. (1986). Holbæk i hundrede år. O. 1880-1980. Fra Kornhandelsby til storkommune. Holbæk: Holbæk Kommune.

Holbæk Amtstidende (1950, 13. maj). Sygehusvæsenets opgaver bør fordeles paa alle sygehuse.

Holbæk Amtstidende (1950, 30. juni). De nye, moderne funktionærboliger vil nok friste sygeplejerskerne.

Holbæk Amtstidenden (1951, 20 januar). Om at være læge i den rette tid. Holbæk Amtstidende (1952, 28. oktober). En brudefærd paa Centralsygehuset.

Holbæk Amtstidende (1956, 18. august). 25 aars barmhjertighedsgerning paa Sct. Elisabeths hospital. Holbæk Amtstidende (1959, 24. december). Mens vi andre holder jul.

Holbæk Amtstidende (1960, 3. februar). Det er mennesker, vi behandler og ikke organer. Holbæk Amtstidende (1962, 28. juni). Centralsygehuset sikrer sig værdifulde arealer. Holbæk Amts Venstreblad (1949, 20. juni). Kirurgerne staar med langt bedre muligheder nu end før. Holbæk Amts Venstreblad (1952, 5. april). Man maa ikke glemme det sjælelige i sygeplejen. Holbæk Amts Venstreblad (1952, 21. juni). Patienterne gør morgengymnastik i sengene paa Centralsygehuset.

Holbæk Amts Venstreblad (1953, 17. november). Øget tilgang til sygeplejen, men behovet er ikke dækket.

Holbæk Amts Venstreblad (1960, 30 december). Jeg kunne ikke tænke mig at være andet end læge. Holbæk Amts Venstreblad (1962, 7. juli). Et halvt hundrede sygehjælpere gledet ind $i$ hospitalsarbejdet.

Holbæk Amts Venstreblad (1964, 8. december). Indstilling om et plejehjem i tilknytning til hvert sygehus.

Holbæk Amts Venstreblad (1966, 26. marts). Ti plejehjem i Holbæk amt anslaaet til 50 mill. kroner. Holbæk Amts Venstreblad (1967, 21. marts). Den nye sygehusfløj i Holbæk kan tages i brug om faa dage.

Holbæk Amts Venstreblad (1969, 12. juli). Tak for 19 gode arbejdsår på centralsygehuset i Holbæk. Holbæk Amts Venstreblad (1974, 5. januar). En fordobling af antallet af de 80-årige kan ventes $i$ året 2000.

Holbæk Amts Venstreblad (1977, 7. juli). Centralsygehuset ind i ny uddannelse. Holbæk Centralsygehus (1974a). Forsidefoto med teksten "Morgenkonference på afdeling A4". Sygehuset - Informationsblad for personalet ved sygehusvæsenet i Holbæk, juli 1974 (13). 
Holbæk Centralsygehus (1974b). Sygehusvæsenet i Holbæk (oversigt). Sygehuset - Informationsblad for personalet ved sygehusvæsenet i Holbæk, juli 1974 (13).

Holbæk Sygehus (2017). Geriatrisk team. Region Sjællands Internetportal. Hentet fra: http://www.regionsjaelland.dk/sundhed/geo/holbaeksygehus/afdelinger/medicinskafdeling/Geriatri/Sider/Geriatrisk-team.aspx

Holbæk Sygehus (2018). Patient- og pårørenderåd. Region Sjællands Internetportal. Hentet fra: http://www.regionsjaelland.dk/sundhed/geo/holbaeksygehus/praktisk/raad-og-vejledning-tilpatienter/patient-og-paaroerenderaad/Sider/Patient-paaroerenderaad.aspx

Høgsgaard, D. (2016). Tværsektoriel samarbejde og kommunikation imellem sundhedsprofessionelle, når ældre patienter udskrives. Aktionsforskning om forandringslyst, kompleksitet og styring i et sundhedsvæsen under pres (Ph.d.-afhandling). Roskilde Universitet. Hentet fra: https://ruc.dk/sites/default/files/2017-03/Afhandling-Ditte-Hoegsgaard.pdf

Højrup, T. (2002). Dannelsens Dialektik. Etnologiske udfordringer til det glemte folk. København: Museum Tusculanums Forlag.

Højrup, T. (2003). Livsformer og velfærdsstat ved en korsvej?: Introduktion til et kulturteoretisk og kulturhistorisk bidrag. Aarhus: Museum Tusculanums Forlag.

Indenrigs- og Sundhedsministeriet (2005). Kommunalreformen - kort fortalt. Hentet fra: http://www.oim.dk/media/17070/kommunalreformen-kort-fortalt.pdf

Jespersen, A., Melchior M. R. \& Sandberg, M. (2006). Verden over: en introduktion til stats- og livsformsteorien og dens aktuelle anvendelse i etnologien. København: Museum Tusculanums Forlag.

Juul Jensen, U. (1986). Sygdomsbegreber i praksis. København: Munksgaard, 2. udgave.

Kirkeskov, A. \& Larsen, T. S. (Red.) (1933). Holbæk Amt. Et historisk-topografisk værk med personalhistoriske oplysninger. København: Amtshistorisk Forlag.

Kjeldstadli, K. (2001). Fortiden er ikke hvad den har været - en indføring i historiefaget. Frederiksberg: Roskilde Universitetsforlag.

Knudsen, C., B. Laulund, A. Andersen m.fl. (1962). Det danske sygehusvæesen. (Bind 1-2). København. Dyva \& Jeppesens Forlag a/s.

Kritzman L. (1988). Power and sex: An interview with Michel Foucault. In: Kritzman L. (ed.) Michel Foucault: Politics, Philosophy, Culture: Interviews and Other Writings, 1977-1984. New York: Routledge.

Leick, C. (2003). Sygeplejersker overtager skadestuerne. Sygeplejersken, Årg. 103 (25), 8-9.

Ministeriet for Sundhed og Forebyggelse (2011). National handlingsplan for den ældre medicinske patient. Hentet fra:

http://sum.dk/Aktuelt/Nyheder/Sundhedspolitik/2011/December/ /media/Filer\%20\%20dokumenter/Handlingsplan-aeldre-medicinsk-patient/National-handlingsplan-for-den$\%$ C3\%A6ldre-medicinske-patient.ashx

Region Sjælland (2012). Driftsaftale 2012 - Sygehus Nord. Hentet fra: http://www.regionsjaelland.dk/dagsordener/dagsordener2012/Documents/1269/1564027.PDF

Region Sjælland (2013). Driftsaftale 2013 - Holbæk Sygehus. Hentet fra: http://www.regionsjaelland.dk/dagsordener/dagsordener2012/Documents/1286/1267296.PDF

Region Sjælland (2015). Politik for sundhedsforskning i Region Sjælland 2015-2018. Hentet fra: http://www.regionsjaelland.dk/Sundhed/forskning/organisationogpolitik/Sider/Forskningsstrategi. $\underline{\text { aspx }}$

Schroll, M. (1983). Geriatri II - Når Gamle Bliver Syge - Olympiadesyndromet. I: A. Viidik (Red.), Aldringens mange facetter. Aarhus: Dansk Gerontologisk Selskab. 
Simper, A. M., Overgaard Andersen, U., Ibsen, H. \& Lysbo Svendsen, T. (2009). Sygeplejebaseret hypertensionsklinik når målet. Sygeplejersken. Årg. 109 (23), 48-53.

Sjællands Posten (1954, 17. februar). I en krigstid mangler sygehusene frivillige sygehjælpere.

Sjællands Posten (1954, 9. marts). Der uddannes en stab af medhjælpere på Centralsygehuset $i$ Holbæk.

Sjællands Tidende (1972, 7. april). Sygehuset indfører nu EDB-registrering.

Sjællands Tidende (1974, 19. december). Forstanderinden ikke sygehusets "skrappe dame".

Steenberger, A. (2009). Nye akutafdelinger rykker nærmere. Ugeskrift for læger. Årg. 171 (6) 446448.

Sundheds- og ældreministeriet (2016). Styrket indsats for den ældre medicinske patient - National handlingsplan 2016. Hentet fra: http://www.sum.dk/ /media/Filer\%20-

\%20Publikationer i pdf/2016/Styrket-indsats-for-den-aeldre-medicinskepatient/National Handlingsplan.ashx.

Vallgårda, S. \& Krasnik, A. (2016). Sundhedsvæsen og sundhedspolitik. København: Munksgaard Danmark. 3. udgave. 